University of Nebraska - Lincoln

DigitalCommons@University of Nebraska - Lincoln

1998

\title{
Biogenic iron mineralization accompanying the dissimilatory reduction of hydrous ferric oxide by a groundwater bacterium
}

James K. Fredrickson

Pacific Northwest National Laboratory, jim.fredrickson@pnl.gov

John M. Zachara

Pacific Northwest National Laboratory, john.zachara@pnl.gov

David Kennedy

Pacific Northwest National Laboratory

Hailang Dong

Princeton University

Tullis Onstott

Princeton University

See next page for additional authors

Follow this and additional works at: https://digitalcommons.unl.edu/usdoepub

Part of the Bioresource and Agricultural Engineering Commons

Fredrickson, James K.; Zachara, John M.; Kennedy, David; Dong, Hailang; Onstott, Tullis; Hinman, Nancy; and $\mathrm{Li}$, Shu-mei, "Biogenic iron mineralization accompanying the dissimilatory reduction of hydrous ferric oxide by a groundwater bacterium" (1998). US Department of Energy Publications. 246.

https://digitalcommons.unl.edu/usdoepub/246

This Article is brought to you for free and open access by the U.S. Department of Energy at DigitalCommons@University of Nebraska - Lincoln. It has been accepted for inclusion in US Department of Energy Publications by an authorized administrator of DigitalCommons@University of Nebraska - Lincoln. 
Authors

James K. Fredrickson, John M. Zachara, David Kennedy, Hailang Dong, Tullis Onstott, Nancy Hinman, and Shu-mei Li

This article is available at DigitalCommons@University of Nebraska - Lincoln: https://digitalcommons.unl.edu/ usdoepub/246 
PII S0016-7037(98)00243-9

\title{
Biogenic iron mineralization accompanying the dissimilatory reduction of hydrous ferric oxide by a groundwater bacterium
}

\author{
James K. Fredrickson, ${ }^{*}, 1$ John M. Zachara, ${ }^{1}$ David W. Kennedy, ${ }^{1}$ Hailang Dong, ${ }^{2}$ Tullis C. Onstott, ${ }^{2}$ Nancy W. Hinman, ${ }^{3}$ \\ and SHU-MEI Li ${ }^{1}$ \\ ${ }^{1}$ Pacific Northwest National Laboratory, Richland, Washington 99352,USA \\ ${ }^{2}$ Princeton University, Department of Geosciences, Princeton, New Jersey 08544, USA \\ ${ }^{3}$ University of Montana, Department of Geology, Missoula, Montana 59812, USA
}

(Received May 1, 1998; accepted in revised form July 24, 1998)

\begin{abstract}
Dissimilatory iron-reducing bacteria (DIRB) couple the oxidation of organic matter or $\mathrm{H}_{2}$ to the reduction of iron oxides. The factors controlling the rate and extent of these reduction reactions and the resulting solid phases are complex and poorly understood. Batch experiments were conducted with amorphous hydrous ferric oxide (HFO) and the DIRB Shewanella putrefaciens, strain CN32, in well-defined aqueous solutions to investigate the reduction of HFO and formation of biogenic Fe(II) minerals. Lactate-HFO solutions buffered with either bicarbonate or 1,4-piperazinediethanesulfonic acid (PIPES) containing various combinations of phosphate and anthraquinone-2,6-disulfonate (AQDS), were inoculated with S. putrefaciens CN32. AQDS, a humic acid analog that can be reduced to dihydroanthraquinone by CN32, was included because of its ability to function as an electron shuttle during microbial iron reduction and as an indicator of pe. Iron reduction was measured with time, and the resulting solids were analyzed by X-ray diffraction, scanning electron microscopy (SEM), and transmission electron microscopy (TEM) with energy-dispersive $\mathrm{X}$-ray spectroscopy (EDS) and selected area electron diffraction (SAED). In $\mathrm{HCO}_{3}^{-}$buffered medium with AQDS, HFO was rapidly and extensively reduced, and the resulting solids were dominated by ferrous carbonate (siderite). Ferrous phosphate (vivianite) was also present in $\mathrm{HCO}_{3}^{-}$medium containing $\mathrm{P}$, and fine-grained magnetite was present as a minor phase in $\mathrm{HCO}_{3}^{-}$medium with or without $\mathrm{P}$. In the PIPESbuffered medium, the rate and extent of reduction was strongly influenced by AQDS and P. With AQDS, HFO was rapidly converted to highly crystalline magnetite whereas in its absence, magnetite mineralization was slower and the final material less crystalline. In PIPES with both $\mathrm{P}$ and AQDS, a green rust type compound $\left[\mathrm{Fe}_{(6-\mathrm{x})}^{\mathrm{II}} \mathrm{Fe}_{\mathrm{x}}^{\mathrm{III}}(\mathrm{OH})_{12}\right]^{\mathrm{x}+}\left[\left(\mathrm{A}^{2-}\right)_{\mathrm{x} / 2} \cdot \mathrm{yH}_{2} \mathrm{O}\right]^{\mathrm{x}-}$ was the dominant solid phase formed; in the absence of AQDS a poorly crystalline product was observed. The measured pe and nature of the solids identified were consistent with thermodynamic considerations. The composition of aqueous media in which microbial iron reduction occurred strongly impacted the rate and extent of iron reduction and the nature of the reduced solids. This, in turn, can provide a feedback control mechanism on microbial metabolism. Hence, in sediments where geochemical conditions promote magnetite formation, two-thirds of the Fe(III) will be sequestered in a form that may not be available for anaerobic bacterial respiration. Copyright (C) 1998 Elsevier Science Ltd
\end{abstract}

\section{INTRODUCTION}

Although the importance of microbial iron reduction in the biogeochemical evolution of anaerobic sediments and soils is well-recognized (Lovely, 1991a, 1993; Nealson and Saffarini, 1994), the interactions between sediment geochemistry and microbial reduction of $\mathrm{Fe}(\mathrm{III})$ oxides are still poorly understood. In particular, the factors controlling the rate and extent of microbial reduction of $\mathrm{Fe}$ (III) oxides and the identity and chemical/mineralogical nature of the products formed are not well known.

Poorly crystalline hydrous ferric oxide (HFO) is a principal form of $\mathrm{Fe}(\mathrm{III})$ oxide reduced by bacteria in anoxic sediments (Lovely and Phillips, 1987). Crystalline Fe(III) oxides ( $\alpha$ $\mathrm{FeOOH}, \mathrm{Fe}_{2} \mathrm{O}_{3}$ ) are also reducible by some microorganisms (e.g., Shewanella; Arnold et al., 1988; Roden and Zachara, 1996) with $\mathrm{Fe}(\mathrm{III})$ availability controlled to a large degree by surface area. Roden and Zachara (1996) showed that the rate and extent of bacterial Fe(III) oxide reduction increased lin-

\footnotetext{
*Author to whom correspondence should be addressed (jim.fredrickson@pnl.gov).
}

early with surface area, regardless of the degree of Fe(III) oxide crystallinity or structural form. Amorphous HFO had the highest surface area, at $\sim 600 \mathrm{~m}^{2} \mathrm{~g}^{-1}$ and was the most extensively reduced among those minerals evaluated.

The reaction of $\mathrm{Fe}(\mathrm{II})$ resulting from microbial reduction appears to influence the overall extent and rate of dissimilatory iron reduction, but details are unclear. Surface saturation of $\alpha$-FeOOH with sorbed, biogenic Fe(II) partially passivated the crystalline oxide surface against further bacterial reduction. Extraction of the surface-sorbed Fe(II) from goethite regenerated surfaces that were further reduced when inoculated with fresh Shewanella alga cells. Similarly, Urrutia et al. (1998) found that pre-adsorption of $\mathrm{Fe}(\mathrm{II})$ to $S$. alga cell surfaces inhibited the rate of HFO and goethite reduction. Phosphate, carbonate, or organic ligands and reactions influencing the speciation of $\mathrm{Fe}(\mathrm{II})$ are expected to be important factors influencing microbial reduction of iron oxides through formation of (1) aqueous complexes and/or (2) ferrous solids that suppress sorption and act as alternative $\mathrm{Fe}(\mathrm{II})$ sinks to the oxide or organism surface. Scientific information supporting such speculation, however, is limited.

Magnetite and siderite are frequently observed products of 
dissimilatory HFO reduction in laboratory cultures. Published results are limited primarily to the dissimilatory iron-reducing bacterium, Geobacter metallireducens strain GS-15. Although the DIRB cultures with $\mathrm{HFO}$ typically contain $\mathrm{PO}_{4}$ in molar concentration, vivianite $\left[\mathrm{Fe}_{3}\left(\mathrm{PO}_{4}\right)_{2} \cdot 8 \mathrm{H}_{2} \mathrm{O}\right]$ formation has only been observed when soluble $\mathrm{Fe}(\mathrm{III})$ (Fe(III)-citrate) has been used as the electron acceptor. The mineral phases observed in these cultures are not thought to be biogenic in the strictest sense (e.g., biomimetic; Lovley et al., 1987; Mortimer and Coleman, 1997), but there is clear evidence for complex interplay between the bacterial reduction process, such as $\mathrm{Fe}$ (II) evolution rate and microenvironment, the aqueous geochemical conditions, including composition, $\mathrm{pH}$, and pe, system kinetics, and thermodynamics, and the surface chemistry of the oxide. These interactions lead to the formation of a dominant phase or produce a phase mixture. The interaction between biotic and abiotic factors involved in mineralization are poorly understood, as are the conditions that dictate the relative distribution of reduced phases, such as magnetite and siderite during microbial Fe(III) reduction. It is well recognized that the metabolism of anaerobic bacteria promotes the formation of magnetite and siderite and that the relative distribution of these phases is, in part, a function of $\mathrm{pH}$ and pe (Bell et al., 1987). The resolution of these factors is critical to understanding processes in environments where magnetite, siderite, and vivianite are observed as diagenetic phases in sediments and groundwaters in which iron reduction is occurring (Emerson, 1976; Emerson and Widmer, 1978; Karlin et al., 1987; Maher and Taylor, 1988; Baedecker et al., 1992).

Dissimilatory reduction of Fe(III) oxides by bacteria in simple, defined systems appears to require direct contact between cells and oxides due to the low solubility of Fe(III) at circumneutral $\mathrm{pH}$ and the association of electron transducing enzymes with the organism surface. However, recent results have demonstrated that the dissimilatory Fe-reducing bacteria Geobacter metallireducens and S. alga can use humic substances and quinones as electron acceptors for respiration (Lovely et al., 1996, 1998). The reduced organic compounds can, in turn, reduce iron oxides, functioning as electron shuttles between the oxides and cells. Such behavior parallels the reductive abiotic dissolution of oxides by hydroquinones. Electron shuttling can significantly increase both the rate and the capacity for iron oxide reduction by microorganisms, apparently by relieving the requirement for cell surface-oxide contact and the attendant surface chemical constraints.

The purpose of this research was to investigate the bacterial reduction of HFO by $S$. putrefaciens and the nature of biogenic secondary phase formation in the presence of different inorganic ligands $\left(\mathrm{PO}_{4}\right.$ and $\left.\mathrm{HCO}_{3}\right)$ under conditions that may promote or suppress the organism/oxide association (i.e., with and without an electron shuttle). The electron shuttle used, anthraquinone-2,6-disulfonate (AQDS), is both a humic acid analog and a soluble redox indicator (Clark, 1960). Our goal was to provide insights on biogeochemical factors governing dissimilatory biogenic mineralization in sediment or groundwater systems. We have investigated the influence of AQDS on the rate and extent of HFO reduction in different buffered systems and utilized X-ray diffraction, scanning electron microscopy (SEM), and transmission electron microscopy (TEM) to evaluate the crystallographic and morphologic features of the
Table 1. Medium composition

\begin{tabular}{|c|c|c|}
\hline Common components & $\begin{array}{c}\text { Concentration, } \\
\text { expt. } 1 \\
\text { M }\end{array}$ & $\begin{array}{c}\text { Concentration, } \\
\text { expts. } 2,3 \\
\mathrm{M}\end{array}$ \\
\hline Hydrous Ferric Oxide & $4.5 \times 10^{-2}$ & $4.5 \times 10^{-2}$ \\
\hline Na lactate & $1.8 \times 10^{-2}$ & $2.7 \times 10^{-2}$ \\
\hline $\mathrm{NH}_{4} \mathrm{CI}$ & $2.2 \times 10^{-2}$ & $2.5 \times 10^{-2}$ \\
\hline $\mathrm{KCl}$ & $1.2 \times 10^{-3}$ & $1.2 \times 10^{-3}$ \\
\hline $\mathrm{CaCl}_{2}$ & $6.1 \times 10^{-4}$ & $6.1 \times 10^{-4}$ \\
\hline Nitrilotriacetic Acid & $7.1 \times 10^{-4}$ & $7.1 \times 10^{-4}$ \\
\hline $\mathrm{MgSO}_{4} \cdot 7 \mathrm{H}_{2} \mathrm{O}$ & $1.1 \times 10^{-3}$ & $1.1 \times 10^{-3}$ \\
\hline $\mathrm{NaCl}$ & $1.5 \times 10^{-3}$ & $1.5 \times 10^{-3}$ \\
\hline $\mathrm{MnSO}_{4} \cdot \mathrm{H}_{2} \mathrm{O}$ & $2.7 \times 10^{-4}$ & $2.7 \times 10^{-4}$ \\
\hline $\mathrm{ZnCl}_{2}$ & $8.6 \times 10^{-5}$ & $8.6 \times 10^{-5}$ \\
\hline $\mathrm{FeSO}_{4} \cdot 7 \mathrm{H}_{2} \mathrm{O}$ & $3.2 \times 10^{-5}$ & $3.2 \times 10^{-5}$ \\
\hline $\mathrm{CaCl}_{2} \cdot 2 \mathrm{H}_{2} \mathrm{O}$ & $6.1 \times 10^{-5}$ & $6.1 \times 10^{-5}$ \\
\hline $\mathrm{CoCl}_{2} \cdot 6 \mathrm{H}_{2} \mathrm{O}$ & $3.8 \times 10^{-5}$ & $3.8 \times 10^{-5}$ \\
\hline $\mathrm{Na}_{2} \mathrm{MoO}_{4} \cdot 2 \mathrm{H}_{2} \mathrm{O}$ & $9.3 \times 10^{-6}$ & $9.3 \times 10^{-6}$ \\
\hline $\mathrm{Na}_{2} \mathrm{WO}_{4} \cdot 2 \mathrm{H}_{2} \mathrm{O}$ & $6.8 \times 10^{-6}$ & $6.8 \times 10^{-6}$ \\
\hline $\mathrm{NiCl}_{2} \cdot 6 \mathrm{H}_{2} \mathrm{O}$ & $9.1 \times 10^{-6}$ & $9.1 \times 10^{-6}$ \\
\hline $\mathrm{CuSO}_{4} \cdot 5 \mathrm{H}_{2} \mathrm{O}$ & $3.6 \times 10^{-6}$ & $3.6 \times 10^{-6}$ \\
\hline $\mathrm{AlK}\left(\mathrm{SO}_{4}\right)_{2} \cdot 12 \mathrm{H}_{2} \mathrm{O}$ & $1.9 \times 10^{-6}$ & $1.9 \times 10^{-6}$ \\
\hline $\mathrm{H}_{3} \mathrm{BO}_{3}$ & $1.5 \times 10^{-5}$ & $1.5 \times 10^{-5}$ \\
\hline Treatment-Specific Components & & \\
\hline $\mathrm{NaHCO}_{3}$ & $2.7 \times 10^{-2}$ & $3.0 \times 10^{-2}$ \\
\hline 1,4-piperazinediethanesulfonic acid & $4.5 \times 10^{-3}$ & $3.0 \times 10^{-2}$ \\
\hline $\mathrm{NaH}_{2} \mathrm{PO}_{4}$ & $3.9 \times 10^{-3}$ & $3.9 \times 10^{-3}$ \\
\hline Anthraquinone-2,6-disulfonate & $1.0 \times 10^{-4}$ & $9.0 \times 10^{-5}$ \\
\hline
\end{tabular}

biogenic precipitates. The biogenic phase association is interpreted in light of aqueous solution conditions, pe, solid phase thermodynamic stability, and microbiological considerations including metabolic status and growth with the intent of identifying unique microbiological contributions to secondary mineralization.

\section{EXPERIMENTAL PROCEDURES}

\subsection{Bacteria and Media}

S. putrefaciens strain CN32 (Subsurface Microbial Culture Collection) was provided courtesy of Dr. David Boone (Portland State Univ.). Strain CN32 was isolated from a subsurface core sample $(250 \mathrm{~m}$ beneath the surface) obtained from the Morrison Formation, a formation mined extensively for $\mathrm{U}$, during drilling of a shale-sandstone sequence in northwestern New Mexico. The sediments were anaerobic at the time of collection based on appearance (blue-green in color) and high $\mathrm{Fe}$ (II) content $\left(>1.5 \mathrm{~g}\right.$ of $0.5 \mathrm{~N} \mathrm{HCl}$-extractable $\left.\mathrm{Fe}(\mathrm{II}) \mathrm{Kg}^{-1}\right)$. Also, groundwater sampled from the overlying Cubero Sandstone had DO below detection $\left(<0.2 \mathrm{mg} \mathrm{L}^{-1}\right)$ and $\mathrm{Fe}(\mathrm{II})$ and $\mathrm{S}^{2-}$ concentrations of 0.8 and $13.6 \mathrm{mg} \mathrm{L}^{-1}$, respectively (Fredrickson et al., 1997). The organism was identified as $S$. putrefaciens by phylogenetic analysis of the 16S rRNA gene sequence (D. Boone and D. L. Balkwill, unpubl. results). CN32 was routinely cultured aerobically in tryptic soy broth (TSB), $30 \mathrm{~g} \mathrm{~L}^{-1}$ (Difco Laboratories, Detroit, MI), and stock cultures were maintained at $-80^{\circ} \mathrm{C}$.

The components in the defined solutions used for the Fe reduction experiments are listed in Table 1; they support growth and metabolism by strain $\mathrm{CN} 32$. The medium was buffered with either $\mathrm{NaHCO}_{3}$ or 1,4-piperazinediethanesulfonic acid (PIPES). Sodium lactate was added as the electron donor and, in select treatments, filter-sterilized $(0.2 \mu \mathrm{m})$ AQDS (Sigma Chemical Co., St. Louis, MO) was added separately. Medium was dispensed into Balch tubes, purged with $\mathrm{O}_{2}$-free $\mathrm{N}_{2}: \mathrm{CO}_{2}$ (80:20) for bicarbonate-buffered medium or $\mathrm{O}_{2}$-free $\mathrm{N}_{2}$ for PIPES-buffered medium, stoppered with butyl rubber closures, and crimp sealed.

CN32 cells were harvested at mid to late log phase, by centrifugation from tryptic soy broth (TSB) cultures, washed with buffer to remove 
residual TSB, resuspended in bicarbonate or PIPES buffer, and purged with $\mathrm{O}_{2}$-free $\mathrm{N}_{2}$. Cells were added to the media to obtain a final concentration of $2-4 \times 10^{8} \mathrm{~mL}^{-1}$.

$\mathrm{HFO}$ was prepared by neutralization of a $\mathrm{FeCl}_{3} \cdot 6 \mathrm{H}_{2} \mathrm{O}$ solution with $\mathrm{NaOH}$ followed by repeated washing with deionized water to remove chloride and sodium (Lovely and Phillips, 1986). HFO prepared in this manner was maintained as an aqueous suspension and added to media to obtain a final concentration of $45 \mathrm{mmol} F e\left(\right.$ III) $\mathrm{L}^{-1}$. Tubes were incubated in the dark at $30^{\circ} \mathrm{C}$ and agitated at $100 \mathrm{rpm}$. Each treatment was replicated three times, and tubes were subsampled or sacrificed at each timepoint for analyses. Controls consisted of solutions that received $1 \mathrm{~mL}$ of sterile, anaerobic buffer in place of CN32 cell suspension. Due to concerns regarding the effect of autoclaving on the properties of the HFO, the oxide was not sterilized for these experiments. Autoclaving is often necessary to eliminate microbial contaminants in synthetic and naturally occurring iron oxides for mechanistic experiments. Such contaminants might flourish in media that contains $\mathrm{P}$ and, therefore, can support growth. Due to potential phase modifications that can occur during heating and pressurization, the oxides were not autoclaved (nonsterile) for most of these studies. A comparative study was performed, therefore, where P-containing medium was autoclaved with HFO before inoculation.

\subsection{Analyses}

At select timepoints, replicate tubes were removed from the incubator and transferred to an anaerobic $\left(\mathrm{Ar}: \mathrm{H}_{2}, 95: 5\right)$ glovebag (Coy Laboratory Products, Inc., Ann Arbor, MI). $1 \mathrm{~mL}$ of suspension was sampled and filtered through a $0.2 \mu \mathrm{m}$ polycarbonate filter directly into $1 \mathrm{~mL}$ of $0.5 \mathrm{~N}$ Ultrex $\mathrm{HCl}$. This fraction was considered to be the soluble fraction and analyzed for Fe(II), phosphate, lactate, acetate, and reduced AQDS, where appropriate. $\mathrm{pH}$ was measured under anaerobic conditions in another aliquot using a Ross combination electrode. $\mathrm{HCl}$-extractable $\mathrm{Fe}(\mathrm{II})$ was obtained by placing $1 \mathrm{~mL}$ of suspension directly into $1 \mathrm{~mL}$ of $1 \mathrm{~N}$ Ultrex $\mathrm{HCl}$, mixing, and allowed to stand for at least $1 \mathrm{~h}$ before analyzing for $\mathrm{Fe}(\mathrm{II})$. This extraction is termed the 0.5 $\mathrm{N} \mathrm{HCl}$ extraction. An extraction with $3 \mathrm{~N} \mathrm{HCl}$ was also used in select experiments because it is effective in the dissolution of most ferrous iron forms expected in these HFO suspensions (Wallmann et al., 1993), with the possible exception of coarse grained magnetite (Jolivet et al., 1992).

$\mathrm{Fe}$ (II) in acidified filtrates $(0.2 \mu \mathrm{m})$ or extracts was determined using the ferrozine assay (Stookey, 1970). Phosphate concentrations were determined using an ammonium paramolybdate assay that is based on formation of a molybdophosphate complex. Lactate and acetate concentrations were determined at the final sampling timepoints by HPLC (Hewlett-Packard 1090) with a Resex organic acid column (Phenomenex). Reduced AQDS was quantified by measuring the absorbance of the reduced form, anthrahydroquinone-2,6-disulfonate (AHDS), at 405 $\mathrm{nm}$. Inorganic carbon was measured on an unacidified aliquot using a Dohrmann Carbon Analyzer and $\mathrm{HCO}_{3}$ computed from the final $\mathrm{pH}$, ionic strength, and ionization constants.

\subsection{X-ray Diffraction}

Mineral residue from the reduction experiments was mixed with glycerol, as a buffer against oxidation, under anaerobic conditions, and the solid slurry was smeared on a glass slide for X-ray diffraction analysis. The slides were maintained under anoxic atmosphere until the time of analysis. The X-ray powder diffraction (XRPD) apparatus consisted of two Philips Wide-Range Vertical Goniometers with incident-beam 2-theta compensating slits, soller slits, fixed $2 \mathrm{~mm}$ receiving slits, diffracted beam graphite monochromators, and scintillation counter detectors. The X-ray source was a Philips XRG3100 X-ray Generator operating a fixed-anode, long-fine-focus $\mathrm{Cu}$ tube at $45 \mathrm{Kv}$, $40 \mathrm{~mA}(1800 \mathrm{~W})$. Instrument control was by means of Databox NIMBIM modules (Materials Data, Inc., Livermore, CA).

\subsection{Electron Microscopy}

Samples were prepared in an anaerobic glovebox to prevent oxidation of $\mathrm{Fe}$ (II)-containing solids. Individual grains of suspension solids were dispersed onto carbon-coated $\mathrm{Cu}$ grids and allowed to dry in the glovebox. The $\mathrm{Cu}$ grids were carefully placed into Balch tubes with crimp seals for transport to the electron microscopes. The only exposure to air occurred during transfer from the tubes to the sample holder and chamber. Samples were examined by SEM to obtain crystal morphology information using a Philips XL30 FEG SEM fitted with backscatter and secondary electron detectors and an IMIX energy dispersive X-ray analytical system. All SEM images were secondary electron images. TEM observations were made with a Philips CM200 FEG TEM fitted with an IMIX analytical system. The TEM was operated at $200 \mathrm{kV}$ and beam voltage of $3.8 \mathrm{kV}$. A $10 \mu \mathrm{m}$ objective aperture was used for imaging. A $10 \mu \mathrm{m}$ selected-area aperture and various camera lengths were used to obtain selected area electron diffraction (SAED) patterns. Qualitative energy dispersive spectrum (EDS) chemical analyses were obtained in TEM mode by focusing the beam to a spot over the target area.

\subsection{Thermodynamic Calculations}

Thermodynamic calculations were performed to assess the degree of solubility equilibrium of the biogenic precipitates and to identify stable solid phase mineral assemblages as a function of pe, $\mathrm{pH}$, buffer composition, and $\mathrm{P}$ concentration. These calculations were performed with the MINTEQA2 code (Allison et al., 1991) and a thermodynamic data base assembled by the authors that contained the best available equilibrium constants for pertinent aqueous species and solid phases. Sources of thermodynamic data for the $\mathrm{Fe}^{2+}-\mathrm{CO}_{3}^{2-}-\mathrm{H}_{2} \mathrm{O}$ and the $\mathrm{Fe}^{2+}$ $\mathrm{PO}_{4}^{3-}-\mathrm{H}_{2} \mathrm{O}$ were Bruno et al. (1992) and Al-Borno and Tomson (1994), respectively. Thermodynamic data from Smith and Martell (1997) and Wagman et al. (1982) were also used.

Due to the uncertainty in the composition (e.g., $\mathrm{Fe}(\mathrm{II}) / \mathrm{Fe}$ (III) ratio and anion identity and concentration) and free energy of the suspected product (green rust), treatment 5 was not modeled although we note that some thermodynamic data are available for a specific compositional phase with sulphate interlayers (Hansen et al., 1994). For the bicarbonate buffer, we fixed the activity of $\mathrm{CO}_{3}^{2-}$ at a value consistent with the measured bicarbonate concentration and $\mathrm{pH}$ (e.g., $\alpha \mathrm{CO}_{3}^{2-}=$ $1.61 \times 10^{-4}$ for treatment 1 ). In addition to the $\mathrm{NaHCO}_{3}$ in the bicarbonate media, the headspace contained $20 \% \mathrm{CO}_{2(\mathrm{~g})}$ which was assumed to establish a constant activity boundary condition for carbonate. The chemical components modeled included $\mathrm{H}^{+}, \mathrm{e}^{-}$, and acetate (as defined/fixed in Table 2); $\mathrm{Ca}, \mathrm{K}, \mathrm{Na}, \mathrm{Mg}, \mathrm{Cl}, \mathrm{SO}_{4}$, and $\mathrm{PO}_{4}$ as defined in Table 1; and $\mathrm{Fe}$ added as $\mathrm{Fe}(\mathrm{OH})_{3}$. For the PIPES buffer, $\mathrm{H}^{+}, \mathrm{e}^{-}$, $\mathrm{HCO}_{3}^{-}$, and acetate were defined/fixed as in Table 2; PIPES (@ $10^{-3}$ mol L ${ }^{-1}$ ) was included to fix the ionic strength; and the other components were defined as per the bicarbonate media. Siderite, magnetite, and vivianite were considered permissible solids (e.g, allowed to precipitate in competition with the other phases if S.I. $>0$ ) in each buffer simulation. For both buffer systems, the phases computed to be stable at equilibrium under the $\mathrm{pH}$, and pe conditions were consistent with those present at the end of the incubation period (Table 2).

\section{RESULTS}

\subsection{Effect of Buffer Type, Phosphate, and AQDS on Reduction of HFO}

The presence of the humic analogue AQDS at $100 \mu \mathrm{M}$ stimulated the reduction of HFO by cell suspensions of $S$. putrefaciens $\mathrm{CN}-32$, but the effect was modified by the type of buffer and presence of $\mathrm{PO}_{4}^{3-}$ (Fig. 1). In the results that follow, we use the $\mathrm{Fe}(\mathrm{II})$ concentration in the $0.5 \mathrm{~N}$ extraction as a measure of the total extent of reduction. The efficiency of this extraction is discussed later.

The effect of AQDS was particularly pronounced in the $\mathrm{HCO}_{3}^{-}$buffered medium with $4 \mathrm{mM} \mathrm{P}$ where $>88 \%$ of the HFO was reduced within seven days (i.e., $88 \%$ of the total $\mathrm{Fe}$ was obtained as $\mathrm{Fe}(\mathrm{II})$ in the $0.5 \mathrm{~N} \mathrm{HCl}$ extraction). In the absence of AQDS and $\mathrm{P}$, the reduction of Fe(III) was substantially greater in the $\mathrm{HCO}_{3}^{-}$than in the PIPES-buffered medium. These results contrast with previous findings with a medium 
Table 2. Mineral solids, saturation indicies, and solution composition in various media treatments

\begin{tabular}{|c|c|c|c|c|c|c|c|c|}
\hline Treatment no. & 1 & 2 & 3 & 4 & 5 & 6 & 7 & 8 \\
\hline $\mathrm{pH}$ & 8.1 & 7.4 & 7.6 & 7.1 & 7.9 & 7.8 & 7.3 & 7.1 \\
\hline $\mathrm{pe}^{\mathrm{a}}$ & -4.85 & & -4.49 & & -3.40 & & -3.47 & \\
\hline I & 0.146 & 0.145 & 0.136 & 0.154 & 0.098 & 0.10 & 0.092 & 0.084 \\
\hline \multicolumn{9}{|l|}{$[\mathrm{mol} / \mathrm{L}]$} \\
\hline $\mathrm{Ca}$ & $6.10 \times 10^{-4}$ & $6.10 \times 10^{-4}$ & $6.10 \times 10^{-4}$ & $6.10 \times 10^{-4}$ & $6.10 \times 10^{-4}$ & $6.10 \times 10^{-4}$ & $6.10 \times 10^{-4}$ & $6.10 \times 10^{-4}$ \\
\hline $\mathrm{Fe}(\mathrm{II})$ & $7.8 \times 10^{-5}$ & $3.9 \times 10^{-4}$ & $1.44 \times 10^{-4}$ & $1.11 \times 10^{-3}$ & $1.12 \times 10^{-3}$ & $1.49 \times 10^{-3}$ & $1.95 \times 10^{-3}$ & $1.23 \times 10^{-3}$ \\
\hline $\mathrm{K}$ & $1.17 \times 10^{-3}$ & $1.17 \times 10^{-3}$ & $1.17 \times 10^{-3}$ & $1.17 \times 10^{-3}$ & $1.17 \times 10^{-3}$ & $1.17 \times 10^{-3}$ & $1.17 \times 10^{-3}$ & $1.17 \times 10^{-3}$ \\
\hline $\mathrm{Na}$ & $6.89 \times 10^{-2}$ & $6.89 \times 10^{-2}$ & $6.30 \times 10^{-2}$ & $6.29 \times 10^{-2}$ & $5.11 \times 10^{-2}$ & $5.10 \times 10^{-2}$ & $4.52 \times 10^{-2}$ & $4.51 \times 10^{-2}$ \\
\hline $\mathrm{Mg}$ & $1.1 \times 10^{-3}$ & $1.1 \times 10^{-3}$ & $1.1 \times 10^{-3}$ & $1.1 \times 10^{-3}$ & $1.1 \times 10^{-3}$ & $1.1 \times 10^{-3}$ & $1.1 \times 10^{-3}$ & $1.1 \times 10^{-3}$ \\
\hline $\mathrm{Cl}$ & $2.48 \times 10^{-2}$ & $2.48 \times 10^{-2}$ & $2.48 \times 10^{-2}$ & $2.48 \times 10^{-2}$ & $2.48 \times 10^{-2}$ & $2.48 \times 10^{-2}$ & $2.48 \times 10^{-2}$ & $2.48 \times 10^{-2}$ \\
\hline $\mathrm{HCO}_{3}$ & $3.88 \times 10^{-2}$ & $3.75 \times 10^{-2}$ & $3.63 \times 10^{-2}$ & $3.44 \times 10^{-2}$ & $8.08 \times 10^{-3}$ & $4.76 \times 10^{-3}$ & $3.43 \times 10^{-3}$ & \\
\hline $\mathrm{PO}_{4}$ & $1.82 \times 10^{-4}$ & $3.41 \times 10^{-5}$ & & & & & & \\
\hline $\mathrm{SO}_{4}$ & $1.3 \times 10^{-3}$ & $1.3 \times 10^{-3}$ & $1.3 \times 10^{-3}$ & $1.3 \times 10^{-3}$ & $1.3 \times 10^{-3}$ & $1.1 \times 10^{-3}$ & $1.3 \times 10^{-3}$ & $1.3 \times 10^{-3}$ \\
\hline Acetate & $1.15 \times 10^{-2}$ & $1.07 \times 10^{-2}$ & $9.55 \times 10^{-3}$ & $7.67 \times 10^{-3}$ & $8.08 \times 10^{-3}$ & $4.76 \times 10^{-3}$ & $3.43 \times 10^{-3}$ & \\
\hline \multicolumn{9}{|l|}{ S.I. ${ }^{\mathrm{b}}$} \\
\hline Calcite & 0.874 & 0.180 & 0.384 & -0.173 & 0.133 & -0.187 & -0.827 & \\
\hline Magnetite & 5.42 & & 3.06 & & 10.45 & & 6.135 & \\
\hline Siderite & 1.58 & 2.09 & 1.49 & 2.19 & 2.47 & 2.274 & 1.752 & \\
\hline Vivianite & 3.37 & 3.99 & & & 3.47 & 5.02 & & \\
\hline Wastite & -0.159 & -.829 & -0.848 & -0.969 & 0.687 & 0.621 & -0.243 & -0.816 \\
\hline $\mathrm{Fe}(\mathrm{OH})_{2}$ & -1.37 & -2.04 & -2.062 & -2.183 & -0.52 & -0.593 & -1.456 & -2.030 \\
\hline \multicolumn{9}{|l|}{ Observed Solids ${ }^{\mathrm{c}}$} \\
\hline XRD & $\begin{array}{l}\text { Siderite/ } \\
\text { vivianite }\end{array}$ & $\begin{array}{l}\text { Siderite/ } \\
\text { vivianite }\end{array}$ & Siderite & Siderite & $\mathrm{Gr}^{\mathrm{e}}$ & $\mathrm{Pc}^{\mathrm{f}}$ & Magnetite & Magnetite \\
\hline \multirow[t]{2}{*}{ Signal: noise } & Very low & Low & Moderate & High & High & Very high & Very low & Very low \\
\hline & Siderite/ & & Siderite/ & & & & & \\
\hline SEM/TEM & vivianite & nd & magnetite & nd & $\mathrm{Gr}^{\mathrm{e}}$ & nd & Magnetite & nd \\
\hline Relative abundance & $\begin{array}{c}\text { Dominant/ } \\
\text { minor }\end{array}$ & & $\begin{array}{l}\text { Dominant/ } \\
\text { minor }\end{array}$ & & $\begin{array}{l}\text { Equally } \\
\text { abundant }\end{array}$ & & Dominant & \\
\hline Stable Solid ${ }^{\mathrm{d}}$ & $\begin{array}{l}\text { Siderite } \\
\text { vivianite }\end{array}$ & & Siderite & & $?^{\mathrm{g}}$ & & Magnetite & \\
\hline
\end{tabular}

${ }^{a}$ From AQDS speciation.

${ }^{\mathrm{b}} \log \frac{\mathrm{IAP}}{\mathrm{K}_{\mathrm{sp}}}$.

${ }^{\mathrm{c}}$ By $\mathrm{x}$-ray diffraction.

d Thermodynamically stable solid.

e Green rust.

${ }^{\mathrm{f}}$ Poorly crystalline.

${ }^{\mathrm{g}}$ Appropriate data not available for calculation.

nd $=$ not determined

surface area $\left(55 \mathrm{~m}^{2} \mathrm{~g}^{-1}\right)$ goethite and $S$. alga BrY where the amount of $\mathrm{Fe}(\mathrm{III})$ reduced after 30d incubation in PIPES and bicarbonate-buffered media was similar. Although the concentration of PIPES and $\mathrm{HCO}_{3}^{-}$were different (Table 1) in this first experiment, the $\mathrm{pH}$ of the two media at $\mathrm{t}=20 \mathrm{~d}$ were nearly identical at $7.09 \pm 0.01$ and $7.14 \pm 0.21$, respectively, ruling out $\mathrm{pH}$ effects. The presence of $\mathrm{PO}_{4}^{3-}$, with or without AQDS increased the reduction of $\mathrm{Fe}(\mathrm{III})$ by $S$. putrefaciens (Fig. 1). Although $\mathrm{P}$ can promote bacterial growth, relatively high concentrations $\left(2-4 \times 10^{8} \mathrm{~mL}^{-1}\right)$ of cells were added at the beginning of the experiment. At $\mathrm{t}=20 \mathrm{~d}$, cell densities, as determined by acridine orange direct counts, ranged from 1.0 to $2.8 \times 10^{8}$ cells $\mathrm{mL}^{-1}$ for all treatments. Thus, the enhanced reduction of $\mathrm{Fe}$ (III) in the presence of $4 \mathrm{mM} \mathrm{P}$ was not due to changes in cell population size.

The concentration of $\mathrm{Fe}_{(\text {(a) }}^{2+}$ observed during the course of incubation differed between buffer systems. In general, aqueous $\mathrm{Fe}(\mathrm{II})$ was well below that associated with the solid as extracted by $\mathrm{HCl}$ (i.e., Fig. 1) indicating that sorption or precipitation dominated the partitioning of biogenic Fe(II). In the $\mathrm{HCO}_{3}^{-}$-buffered medium, $\mathrm{Fe}_{(\mathrm{aq})}^{2+}$ initially increased to $6 \mathrm{mM}$ in the medium without AQDS or P, but it declined in all treatments by $\mathrm{t}=20 \mathrm{~d}$ (Fig. 1c). In the PIPES-buffered medium (Fig. 1d), a peak in $\mathrm{Fe}_{(\text {aq) }}^{2+}$ concentration followed by a decrease, similar to the $\mathrm{HCO}_{3}^{-}$-buffered media was only observed in the AQDS + P treatment. In all of the other PIPES-buffered media, $\mathrm{Fe}_{(\mathrm{aq})}^{2+}$ slowly increased over the course of the experiment. After $20 \mathrm{~d}$ incubation, the $\mathrm{Fe}_{(\mathrm{aq})}^{2+}$ concentration ranged between 1.1 and $2.0 \mathrm{mM}$ for all of the PIPES-buffered media. The concentration of soluble $\mathrm{PO}_{4}^{3-}$, in those treatments where it was added, rapidly declined from $4 \mathrm{mM}$ at $\mathrm{t}=0$ to near analytical detection by $\mathrm{t}=4 \mathrm{~d}$ (Fig. 2). Only in the $\mathrm{HCO}_{3}^{-}$-buffered medium with AQDS $+\mathrm{P}$ did the soluble $\mathrm{P}$ concentrations increase significantly by the end of the experiment.

Both $\mathrm{Fe}_{(\text {aq) }}^{2+}$ and $\mathrm{PO}_{4}^{3-}$ are strongly sorbed by $\mathrm{HFO}$ at the $\mathrm{pH}$ of the reduction experiments (Fig. 3). Fractional sorption of $\mathrm{Fe}_{(\mathrm{aq})}^{2+}$ and $\mathrm{PO}_{4}^{3-}$ would be higher in the biotic incubations because the concentration of HFO was fourfold higher (45 $\mathrm{mM}$ ) than that of the abiotic incubations. Accordingly, relatively little of the $4 \mathrm{mM} \mathrm{PO}_{4}^{3-}$ was observed in the aqueous phase even at the time of inoculation (Fig. 2). The initial sorption of both solutes results from surface complexation, but 

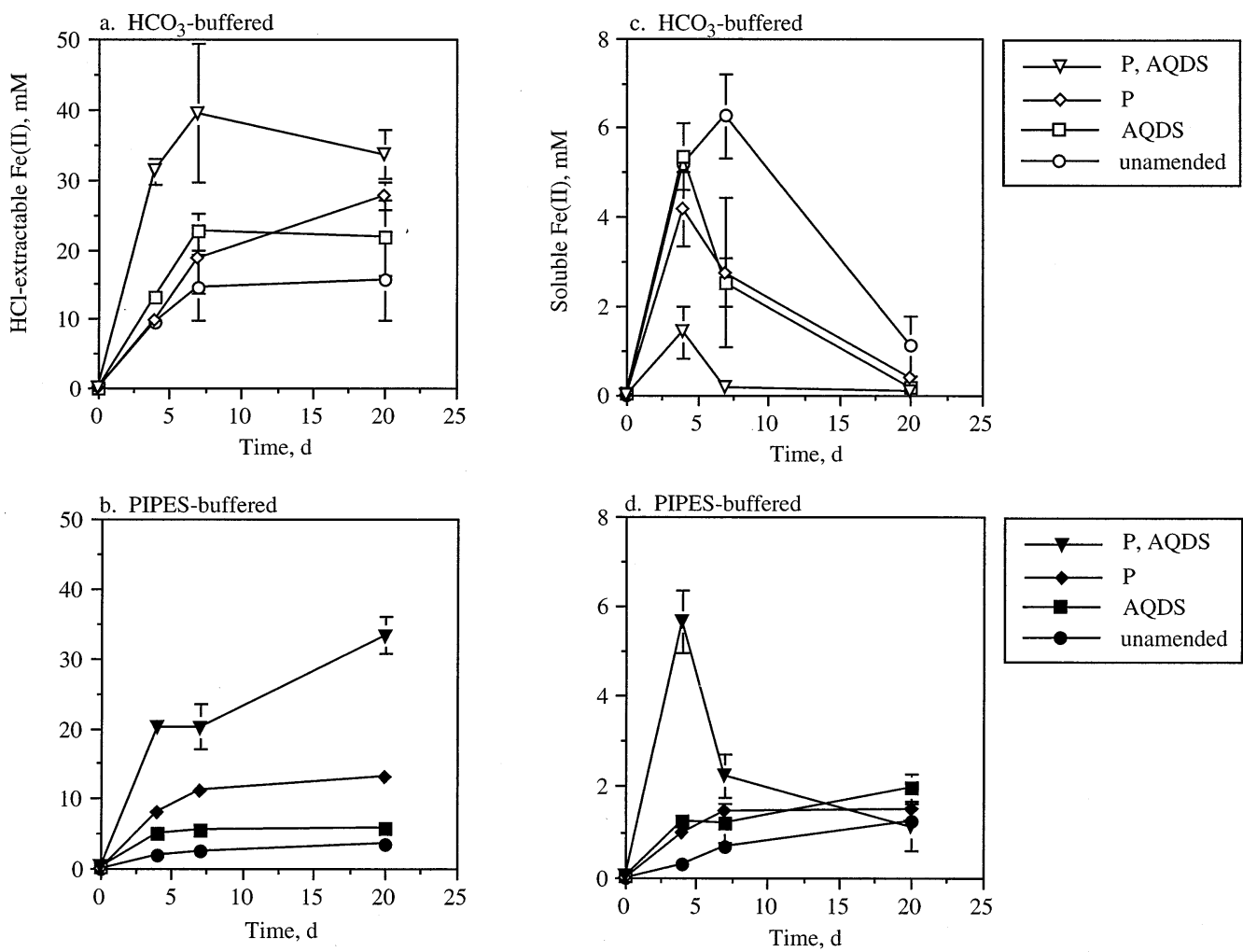

Fig. 1. HCl-extractable Fe(II) in bicarbonate (a) and PIPES (b) buffered HFO suspensions inoculated with S. putrefaciens CN32 extracted with $0.5 \mathrm{~N} \mathrm{HCl}$ in experiment 1 . Soluble $(0.2 \mu \mathrm{m}$-filtered) $\mathrm{Fe}(\mathrm{II})$ in bicarbonate (c) and PIPES (d) buffered solutions in experiment 1.

coprecipitation and topotactic phase conversion can occur with time. The added phosphate was HFO-associated at the beginning of the incubation and the Fe(II) evolved would have sorbed to the residual HFO.

We noted that autoclaving HFO in the presence of $\mathrm{P}$ yielded a solid that was comparable in both color and apparent aggregate structure to the starting material. In the absence of $\mathrm{P}$, autoclaved HFO becomes more aggregated and is dark red in color, similar to hematite. Phosphate is known to stabilize ferrihydrite against transformation to crystalline phases (Cornell and Giovanoli, 1985). The rate and extent of microbial

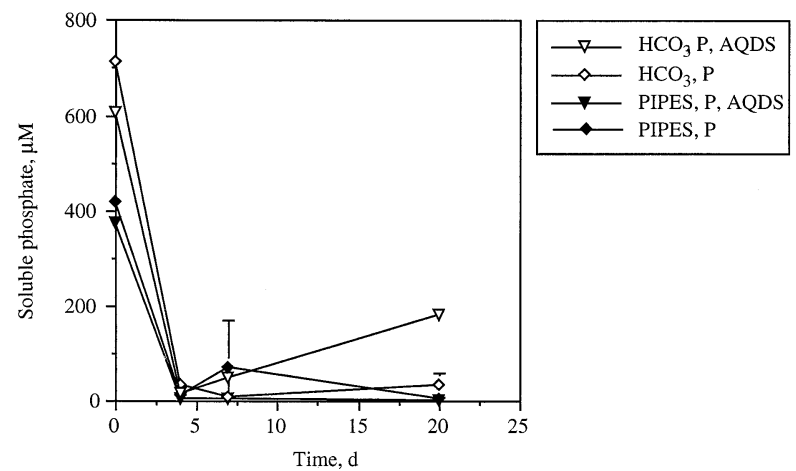

Fig. 2. Soluble (0.2 $\mu \mathrm{m}$-filtered) $\mathrm{PO}_{4}$ in bicarbonate (a) and PIPES (b) buffered solutions in experiment 1 .
$\mathrm{Fe}$ (III) reduction in the autoclaved media with $\mathrm{P}$ (Fig. 4a) was comparable to the reduction in nonautoclaved media (Fig. 1a,b). The soluble Fe(II) concentrations were in good agreement between the two experiments except for the PIPESbuffered medium with $\mathrm{P}$ and AQDS where the concentrations of $\mathrm{Fe}_{(\mathrm{aq})}^{2+}$ were higher in the autoclaved (Fig. 4b) than in the nonautoclaved (Fig. 1d) medium. The concentration of Fe(II) extracted by $0.5 \mathrm{~N} \mathrm{HCl}$ in the uninoculated control, $\mathrm{HCO}_{3}^{-}$buffered medium with $\mathrm{P}$ and AQDS was at the analytical

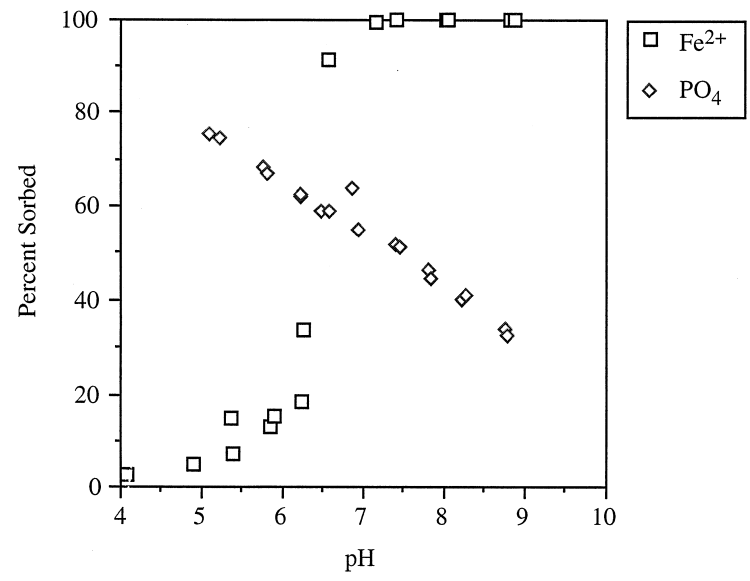

Fig. 3. Isotherm for sorption of $\mathrm{Fe}(\mathrm{II})$ and $\mathrm{PO}_{4}$ on $10 \mathrm{mM}$ HFO. 

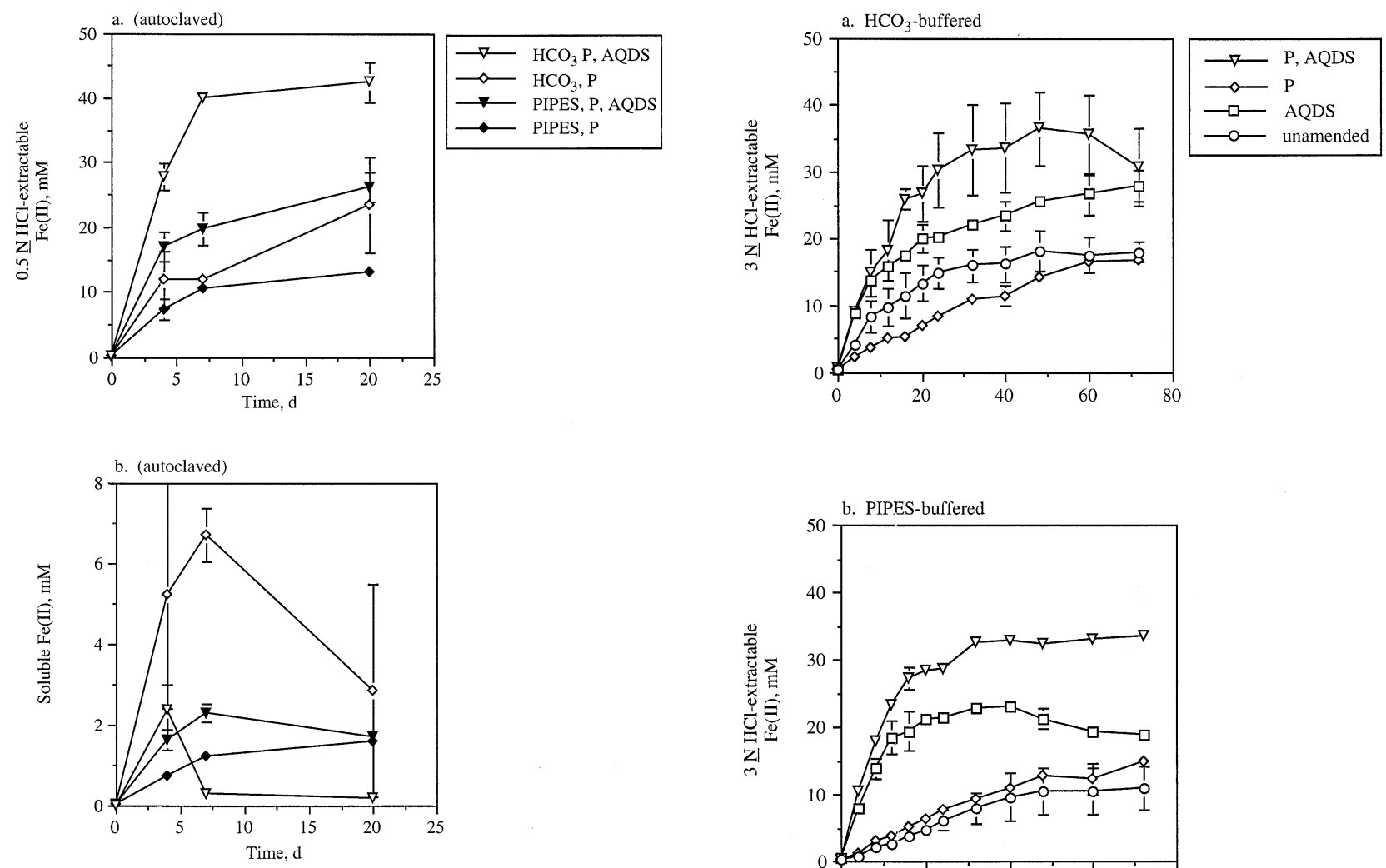

Fig. 4. $\mathrm{HCl}(0.5 \mathrm{~N})$-extractable (a) and soluble (b) $\mathrm{Fe}(\mathrm{II})$ in autoclaved HFO suspensions inoculated with $S$. putrefaciens CN32.

detection limit $(0.5 \mathrm{mM}$ in the undiluted sample) after $20 \mathrm{~d}$ indicating that microbial contaminants, if present, were unable to utilize HFO as an electron acceptor.

In order to better define the kinetics of HFO reduction by $\mathrm{CN} 32$ in the various solutions, an experiment was conducted with shorter sampling intervals. In this experiment, $\mathrm{Fe}(\mathrm{II})$ was measured over periods of several hours, in comparison to days in the previous experiments; for these experiments $3 \mathrm{~N} \mathrm{HCl}$ was used for $\mathrm{Fe}$ (II) extraction to enhance dissolution of iron oxides such as magnetite. The impact of AQDS on the rate of HFO reduction is clearly evident in both the PIPES and $\mathrm{HCO}_{3}^{-}$buffered media, Fig. 5a and b, respectively. The effect of phosphate in combination with AQDS on enhancing the rate and extent of HFO reduction is consistent with the previous experiments that were incubated for days (Figs. 1,2).

\subsection{Reproducibility}

Our laboratory has previously experienced difficulties in reproducing results for the reduction of HFO by another DIRB, Shewanella alga strain BrY. Therefore, a second long-term experiment was conducted with a subset of treatments from the first experiment to assess the reproducibility of results and to measure the reduced form of AQDS, $\mathrm{AH}_{2} \mathrm{DS}$. Although the same general trend with regards to solution composition effects on $\mathrm{Fe}(\mathrm{III})$ reduction were observed in the replicated experiment (Fig. 6), differences did occur. These differences were most notable for those treatments lacking P. For these treatments, the amount of $\mathrm{Fe}(\mathrm{III})$ reduction was generally higher for both the

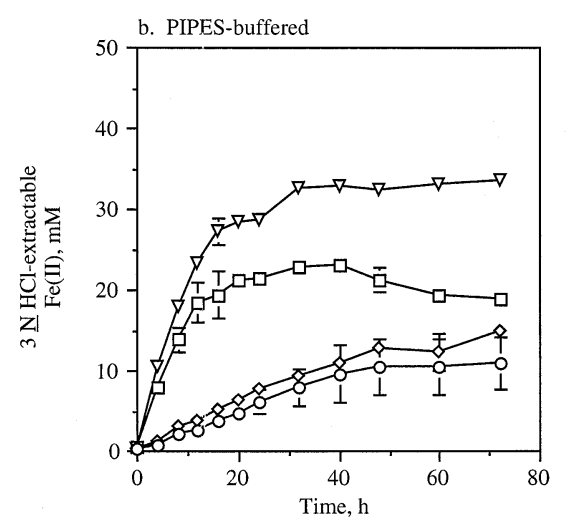

Fig. 5. $\mathrm{HCl}(3 \mathrm{~N})$-extractable Fe(II) in PIPES (a) and bicarbonate (b) buffered solutions inoculated with $S$. putrefaciens $\mathrm{CN} 32$ sampled over short time intervals.

bicarbonate- and PIPES-buffered medium in the second experiment in comparison to the first (Fig. 1). For those media with $\mathrm{P}$, the concentrations of soluble $\mathrm{P}$ in the second experiment at the various timepoints were consistent with those measured in the first experiment. These results illustrate that there was generally good agreement between experiments, and that the difficulties in reproducing results with $S$. alga $\mathrm{BrY}$ were not observed when $S$. putrefaciens CN32 was used.

\subsection{Reduction of AQDS and Calculated pe}

Anthraquinone-2,6-disulfonate is considered to be typical of the quinone and hydroquinone structures in humic acids and is readily reduced to the hydroquinone form $\left(\mathrm{AH}_{2} \mathrm{DS}\right)$ by bubbling $\mathrm{H}_{2(\mathrm{~g})}$ over a palladium catalyst in the presence of AQDS (Kratnyet, 1987). AQDS also functions as an electron acceptor for anaerobic respiration by some bacteria and can act as an electron shuttle for microbial reduction of HFO. Quinones such as AQDS are also excellent indicators of the oxidation-reduction potential of solutions. AQDS was used in our experiments in a dual role, as a soluble electron shuttle and as a redox indicator.

The concentration of $\mathrm{AH}_{2} \mathrm{DS}$ was measured at the various sampling points in the second experiment (Fig. 7) and closely tracked the reduction of the HFO for the various media (Fig. 6a) as defined by $\mathrm{Fe}(\mathrm{II})$ in the $\mathrm{HCl}$ extraction. By $\mathrm{t}=20 \mathrm{~d}$, 

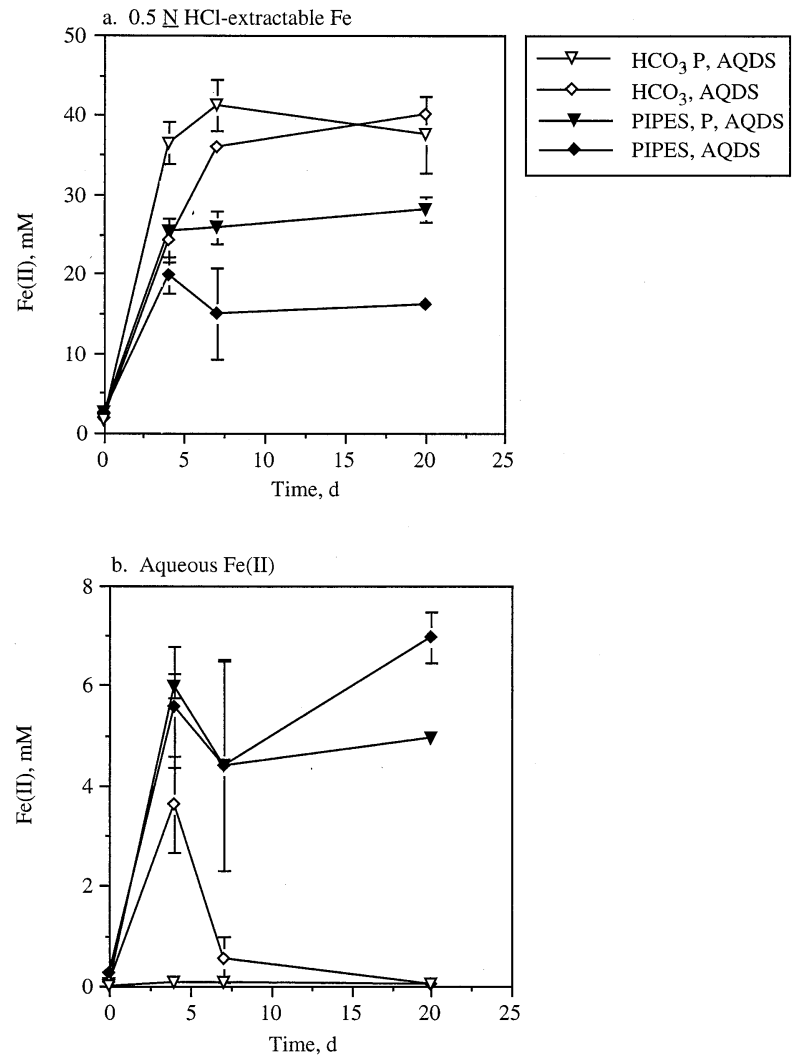

Fig. 6. $\mathrm{HCl}(0.5 \mathrm{~N})$-extractable (a) and soluble (b) $\mathrm{Fe}(\mathrm{II})$ in microbially reduced solids in experiment 2 .

essentially all of the AQDS was in the reduced hydroanthraquinone form in the bicarbonate-buffered media, whereas in the PIPES-buffered media, the concentration of $\mathrm{AH}_{2} \mathrm{DS}$ was $33 \%$ and $62 \%$ of the starting AQDS concentration for media with and without $\mathrm{P}$, respectively.

The final pe of the various media containing AQDS were calculated (Table 2) from the ratio of the oxidized $\left(\mathrm{S}_{\mathrm{o}}\right)$ and reduced $\left(\mathrm{S}_{\mathrm{r}} ;\right.$ Fig. 7) species of AQDS, its $\mathrm{E}_{\mathrm{o}}(0.228 \mathrm{~V})$, and the $\mathrm{pH}$ :

$$
\begin{aligned}
p e=16.9\left\{E_{o}+(R T / n F) \ln \left(S_{o} / S_{r}\right)\right. & +(R T / n F) \ln \left[\left(H^{+}\right)^{2}\right. \\
& \left.+K_{a 1}\left(H^{+}\right)+K_{a 1} K_{a 2}\right\}
\end{aligned}
$$

where $K_{a 1}$ and $K_{a 2}$ are ionization constants of the $\mathrm{AH}_{2} \mathrm{DS}$ $\left(\mathrm{K}_{\mathrm{a} 1}=8 \times 10^{-9}\right.$ and $\left.\mathrm{K}_{\mathrm{a} 2}=3 \times 10^{-11}\right)$. The computed pe's (or redox potential) followed a trend that paralleled the extent of $\mathrm{Fe}(\mathrm{III})$ reduction. Lower pe's were computed in suspensions with greater concentrations of $\mathrm{HCl}$ extractable $\mathrm{Fe}(\mathrm{II})$ and acetate (Table 2), one of the two respiration products (acetate, bicarbonate) of lactate. For example, in the bicarbonate media, $\mathrm{Fe}(\mathrm{II})$ concentrations were higher, and the acetate concentrations were greater than those in the PIPES buffered solutions. Correspondingly, the calculated pe of the bicarbonate solutions were 1-2 log units lower (see Table 2) than they were for the PIPES-buffered treatments.

\subsection{Biogenic Solids}

Solid phase transformation products of HFO were observed in all treatments. All were different in appearance from the

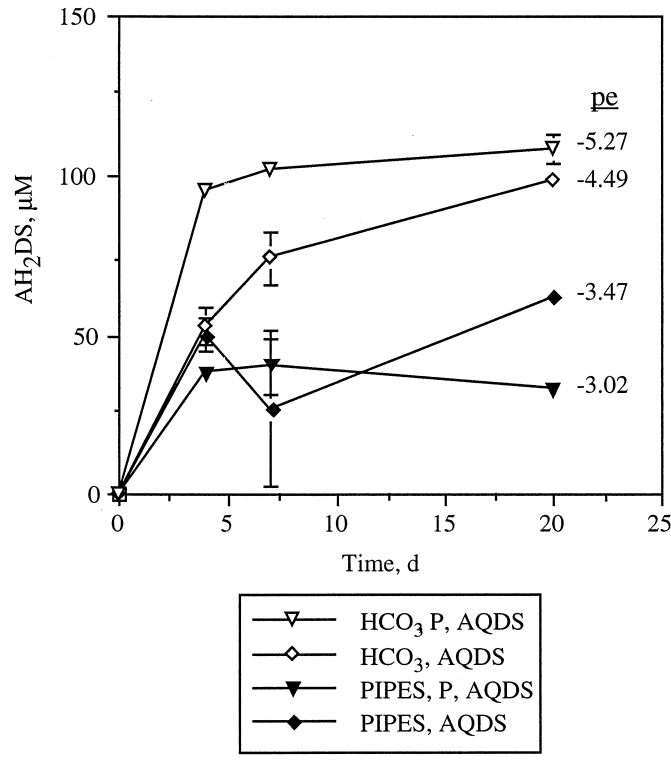

Fig. 7. Changes in concentration of reduced $\left(\mathrm{AH}_{2} \mathrm{DS}\right) 2,6$-anthraquinone disulfonate in HFO suspensions inoculated with $\mathrm{CN} 32$ and final pe, calculated from Eq. (1).

starting material. Solids formed in the bicarbonate buffer were light whitish-gray to whitish-brown to black in comparison to those formed in PIPES buffer that were dark-green to black.

Solids in the bicarbonate buffered media were predominantly siderite $\left(\mathrm{FeCO}_{3}\right.$, Fig. 8a,b). The crystallinity of the solids formed in the presence of AQDS was greater than those formed in its absence, as evidenced by the lower signal to noise ratio of the X-ray diffractograms of the latter samples. With AQDS, the siderite was present as distinct $1-3 \mu \mathrm{m}$ cubic crystallites (Fig. 8c), some of which were linked as chains (Fig. 8d). The SAED pattern obtained from the individual cubic crystals (not shown) exhibited a single crystal diffraction pattern, indicating that the cubes were single crystals, rather than aggregates of smaller particles. In addition to $\mathrm{FeCO}_{3}$, a minor phase of distinct morphology was present that consisted of aggregates of grains several nanometers in size (Fig. 9a). Individual crystals were not resolved at high magnification (above 200,000 $\times$ ) because the crystal boundaries were not clearly defined. The corresponding SAED pattern (Fig. 9b) gave rise to a ring-like powder pattern because the selected area aperture was sufficiently large to include many crystals with random orientations. The indexing of these rings uniquely identified this phase as magnetite.

In the bicarbonate media with $\mathrm{P}, \mathrm{XRD}$ showed the presence of crystalline siderite and vivianite $\left[\mathrm{Fe}_{3}\left(\mathrm{PO}_{4}\right)_{2} \cdot 8 \mathrm{H}_{2} \mathrm{O}\right]$ (Fig. 10a,b). Peak amplitude of both $\mathrm{FeCO}_{3}$ and vivianite was higher with AQDS suggesting that domain size or crystallinity was greater in these samples. The siderite formed with AQDS and $\mathrm{P}$ occurred as aggregates of particles $1-2 \mu \mathrm{m}$ in size (on the right of Fig. 10c), forming characteristic cauliflower-like structures. This morphology was distinct from that observed in bicarbonate-buffered media with AQDS but no P (Fig. 8c,d). The vivianite was found in druses (on the left of Fig. 10c.) exhibiting a prismatic habit with pinacoids. The individual crystals were 5-10 $\mu \mathrm{m}$ long and $0.5-1 \mu \mathrm{m}$ wide. Their SAED 


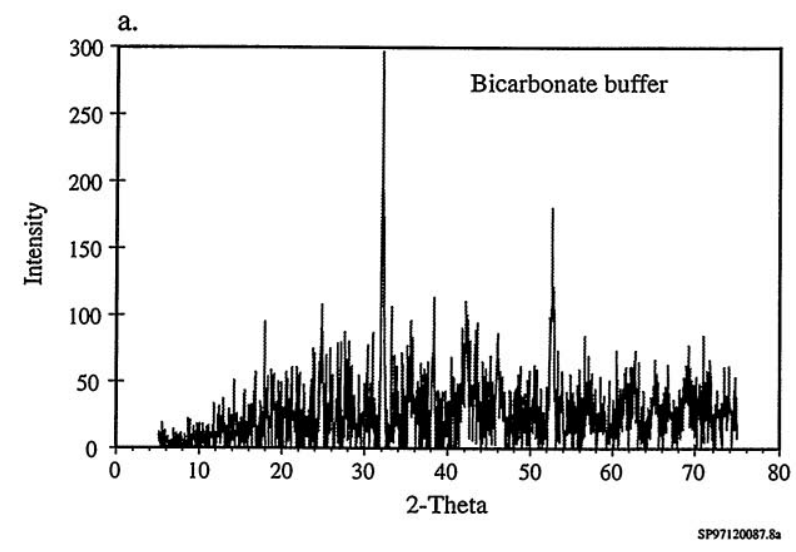

c.

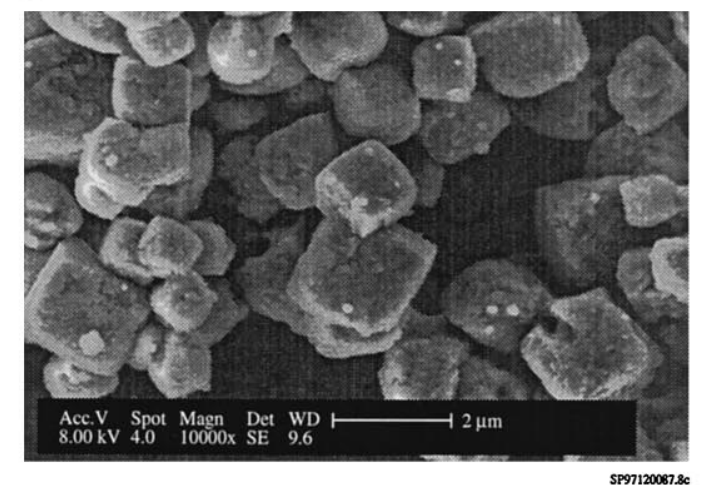

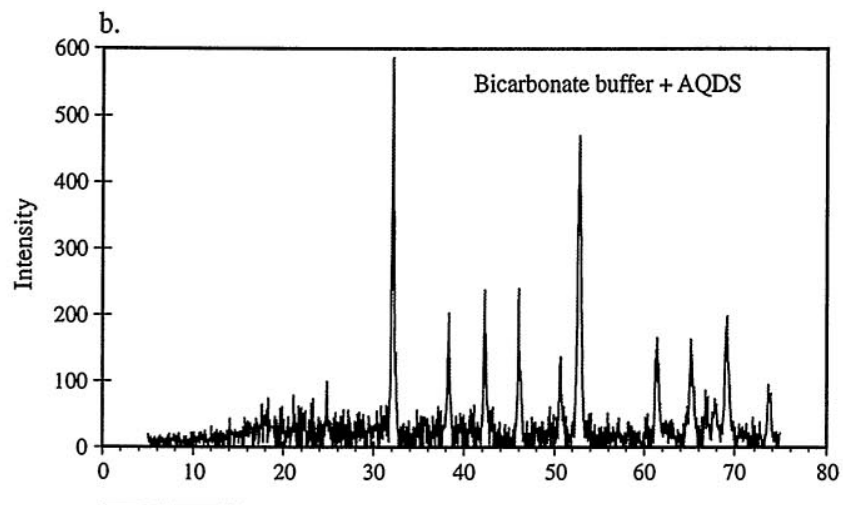

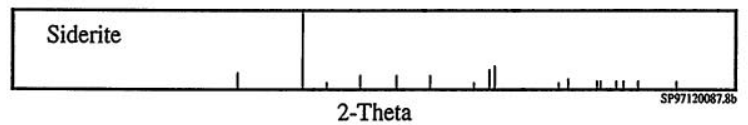

d.

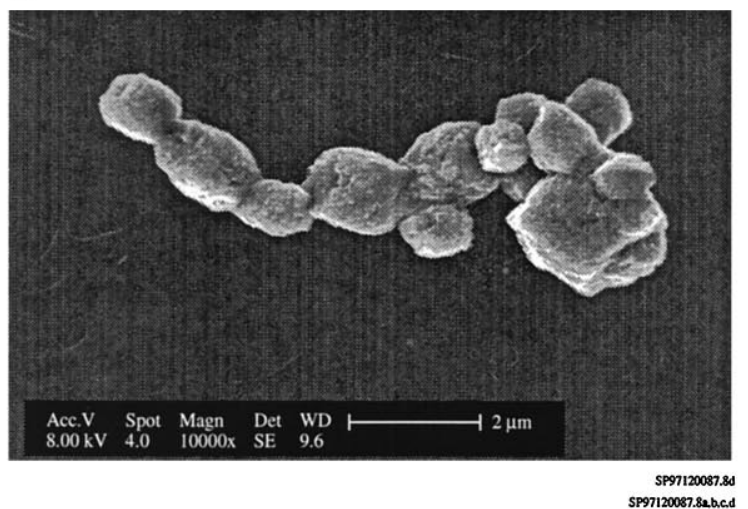

Fig. 8. X-ray diffractograms of microbially reduced Fe solids in bicarbonated-buffered suspensions without (a) and with (b) AQDS, and SEM images of solids from (b) displaying distinctive cubic crystallites (c) some of which were linked as chains (d).

pattern (not shown) was pseudo-hexagonal, suggesting that the vivianite precipitate was of low symmetry. Consistent with vivianite, the EDS analysis of this phase revealed that $\mathrm{Fe}, \mathrm{P}$, and $\mathrm{O}$ were the dominant elements (Fig. 10d).

A greater diversity of solid materials was observed in the PIPES-buffered solution. Crystalline solids were primarily observed when AQDS was present. In absence of P, well crystallized magnetite $\left(\mathrm{Fe}_{3} \mathrm{O}_{4}\right)$ was revealed by XRD (Fig. 11a). The individual crystals of magnetite were not resolvable in SEM, and a typical TEM image of such aggregates (Fig. 11b) revealed poorly defined crystal boundaries. The crystals were nanometers in size and were similar to the fine-grained extracellular biogenic magnetite reported by Sparks et al. (1990). The SAED pattern of these materials exhibited a ring-like powder pattern (not shown) consistent with small crystal size.

When $\mathrm{P}$ was present in the PIPES buffer with AQDS, a poorly crystalline phase was observed that exhibited diffraction maxima (Fig. 12a) consistent with a green rust-type compound (Hansen, 1989; McGill et al., 1976; Vins et al., 1987). Green rusts (GR) are compositionally varied, mixed Fe(II)-Fe(III) hydroxy compounds. Their structure is layered, consisting of positively charged brucite-like sheets with negatively charged, hydrated anion $\left(\mathrm{A}^{2-}\right)$ interlayers; the overall stoichiometric formula is generalized as $\left[\mathrm{Fe}_{(6-\mathrm{x})(\mathrm{aq})}^{\mathrm{II}} \underset{\mathrm{Fe}}{\mathrm{III}}{ }_{\mathrm{x}}(\mathrm{OH})_{12}\right]^{\mathrm{x}+}\left[\left(\mathrm{A}^{2-}\right)_{\mathrm{x} / 2}-\mathrm{yH}_{2} \mathrm{O}\right]^{\mathrm{x}-}$. The
SEM of this precipitate (Fig. 12b) showed the presence of large $(>10 \mu \mathrm{m})$ lath-shaped crystallites that were surrounded by a groundmass of poorly differentiated material. The laths were identified by EDS and SAED as vivianite (as described above), and the groundmass contained a minor fraction of hexagonal shaped crystallites (Fig. 12c) that ranged in diameter from 0.5 to $1 \mu \mathrm{m}$ and that were similar in morphology to GR described by McGill et al. (1976) and Mann et al. (1989). These crystals possessed a layered growth habit with individual layers (plates) stacking normal to (0001) face of the prism (Fig. 12c). In addition to these prisms, a minor fine-grained phase was present on some of the (0001) faces of the prism (Fig. 12c). The EDS analyses of the well-formed prism revealed $\mathrm{O}, \mathrm{Fe}, \mathrm{Na}, \mathrm{Al}$, $\mathrm{Si}, \mathrm{P}, \mathrm{S}$, and $\mathrm{Cl}$ (Fig. 12d). The fine-grained material exhibited similar composition but with higher concentrations of $\mathrm{Na}, \mathrm{S}$, $\mathrm{Cl}, \mathrm{P}, \mathrm{Si}$, and lower concentrations of $\mathrm{Al}$ and $\mathrm{Fe}$ (not shown), suggesting that the morphologically varied materials were the same phase. In the PIPES medium without AQDS, the materials were poorly crystalline both with and without $\mathrm{P}$, although nascent peaks of magnetite were observed in both (not shown).

\subsection{Saturation Indicies for Observed Mineral Solids}

Saturation indices $\left[\log \left({ }^{\mathrm{IAP}} / \mathrm{K}_{\mathrm{sp}}\right)\right]$, where IAP $=$ the ion activity product and $\mathrm{K}_{\mathrm{sp}}=$ the solubility product) were calculated 
a.

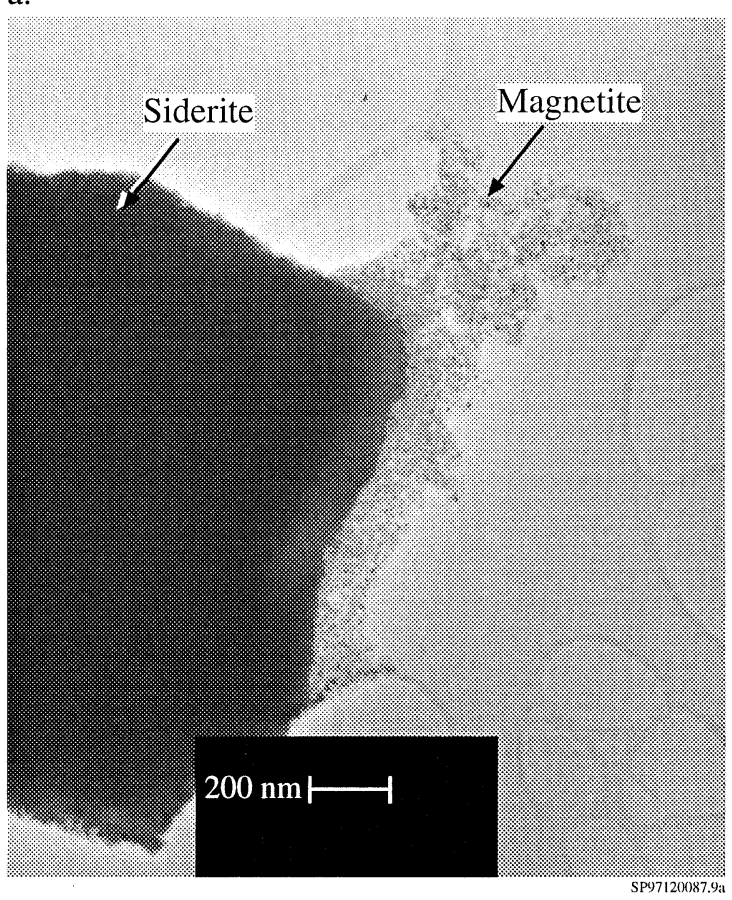

b.

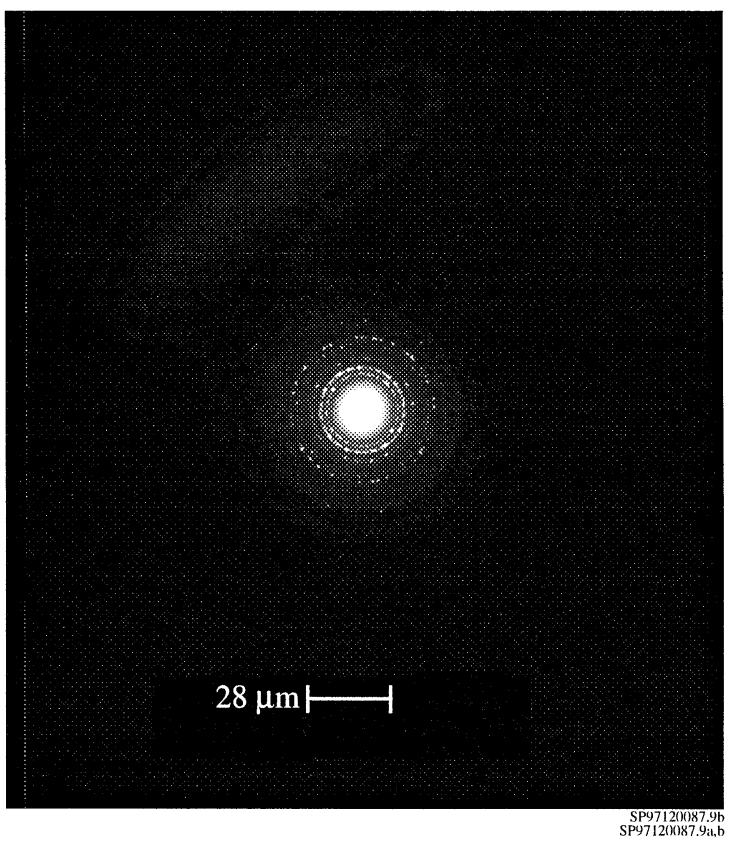

Fig. 9. Transmission electron micrograph of minor-phase Fe solids in bicarbonate-buffered solutions (a) and selected area electron diffraction pattern (b) revealing the solids as magnetite.

for the solid phases noted above (and other relevant ones) for which reliable thermodynamic data exist. The computations used the measured solution compositions and $\mathrm{pH}$ at experiment termination (Table 2). The saturation index (S.I.) is a measure of the extent of solution phase equilibrium with the tested phase. Values in excess of 0 indicate supersaturation and energetics favoring precipitation, and values less then 0 indicate undersaturation and tendency to dissolve. The computations included equilibria for bicarbonate, carbonate, phosphate, sulfate, and acetate complexes. For those incubations that contained AQDS, pe was fixed at the value computed from the $\mathrm{AH}_{2} \mathrm{DS} / \mathrm{AQDS}$ measurement. The extent of solubility equilibrium with respect to magnetite could only be assessed for those incubations where pe was calculated from AQDS speciation.

The saturation indicies (Table 2) indicated that the incubated solutions were oversaturated with respect to the solids that were found within them. Siderite was generally over saturated by 1.5 orders of magnitude (treatments in Table 2), vivianite by 3.45.0 orders of magnitude (treatments 1, 2, and 5), and magnetite by 6.3 orders of magnitude (treatment 7). It is significant that these high degrees of supersaturation persisted from days 7-20, a period over which biotic reductive activity [as determined by change in $0.5 \mathrm{~N} \mathrm{HCl}$ extractable $\mathrm{Fe}(\mathrm{II})]$ was minimal. It appears, therefore, that active solid phase precipitation/formation paralleled microbiological respiration.

One concern regarding the concentration of soluble Fe(II) was that small solids (e.g., fine grained $(100 \mathrm{~nm})$ magnetite) may have passed the membrane filter $(0.2 \mu \mathrm{m})$ and dissolved in the stabilizing acid $(0.5 \mathrm{~N} \mathrm{HCl})$. Another concern was that $\mathrm{Fe}$ (II) might be complexed to cell fragments or cellular macromolecules and that these may have been carried through the filter into acid. Both phenomena would contribute to artificially high $\mathrm{Fe}_{(\mathrm{aq})}^{2+}$ concentrations that would bias S.I. calculations toward oversaturation. Therefore, an assessment of filtration efficiency was performed on yet a third series of microbially reduced HFO suspensions. We found, however, that $\mathrm{Fe}_{(\mathrm{aq})}^{2+}$ concentrations were comparable in $0.2 \mu \mathrm{m}$ and $1.8 \mathrm{~nm}$ filtrates (data not shown), indicating that the passage of Fe(II)-colloidal precipitates or $\mathrm{Fe}(\mathrm{II})$ bound to cell fragments were not the cause of the apparent supersaturation. $\mathrm{Fe}_{(\mathrm{aq})}^{2+}$ concentrations were consistently higher in PIPES buffer (Table 2), however, leading us to speculate that the organic acid buffer components may complex $\mathrm{Fe}(\mathrm{II})$.

\subsection{Extraction Efficiency}

As in previous studies (Roden and Zachara, 1996; Lovley and Phillips, 1988) $0.5 \mathrm{~N} \mathrm{HCl}$ was used to extract Fe(II) that was microbially generated in oxide suspensions and sediments. However, concerns regarding the extraction efficiency of $0.5 \mathrm{~N}$ $\mathrm{HCl}$ for $\mathrm{Fe}(\mathrm{II})$ from residual $\mathrm{HFO}$ and biogenic precipitates prompted a further evaluation using solids from the filtration experiment discussed above. Total Fe [e.g., Fe(II) and Fe(III)] in the $0.5 \mathrm{~N} \mathrm{HCl}$ extraction was determined by reducing $\mathrm{Fe}(\mathrm{III})$ in the extracts to $\mathrm{Fe}(\mathrm{II})$ with hydroxylamine $\mathrm{HCl}$, followed by ferrozine analysis. In addition, the results of the $0.5 \mathrm{~N} \mathrm{HCl}$ extraction of representative incubation suspensions varying in secondary phases were compared to results from a $3 \mathrm{~N} \mathrm{HCl}$ extraction. Often, a solid residue remained after the $0.5 \mathrm{~N} \mathrm{HCl}$ extraction while the $3 \mathrm{~N} \mathrm{HCl}$ extraction typically dissolved all the mineral matter in each incubation suspension. Between $86 \%$ and $98 \%$ of the total $\mathrm{Fe}$ added as HFO was recovered at $20 \mathrm{~d}$ sampling point by $0.5 \mathrm{~N} \mathrm{HCl}$ extraction (Table 3 ), whereas essentially $100 \%$ was obtained by $3 \mathrm{~N} \mathrm{HCl}$ extraction. The 0.5 $\mathrm{N} \mathrm{HCl}$ extraction was able to dissolve most of the biogenic precipitate when it was dominated by siderite, vivianite, or green rust (Table 3). The presence of magnetite, however, lead 


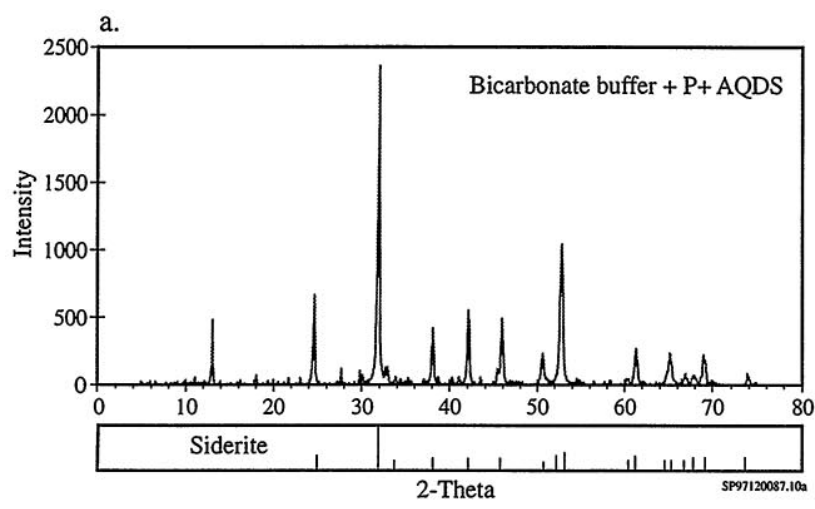

c.

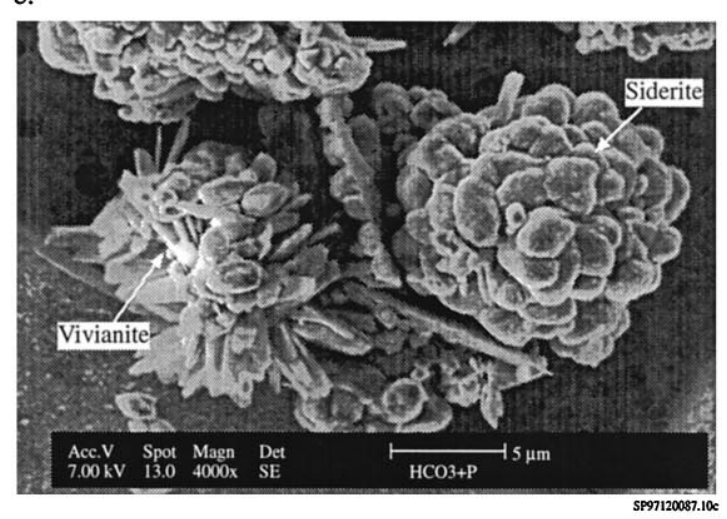

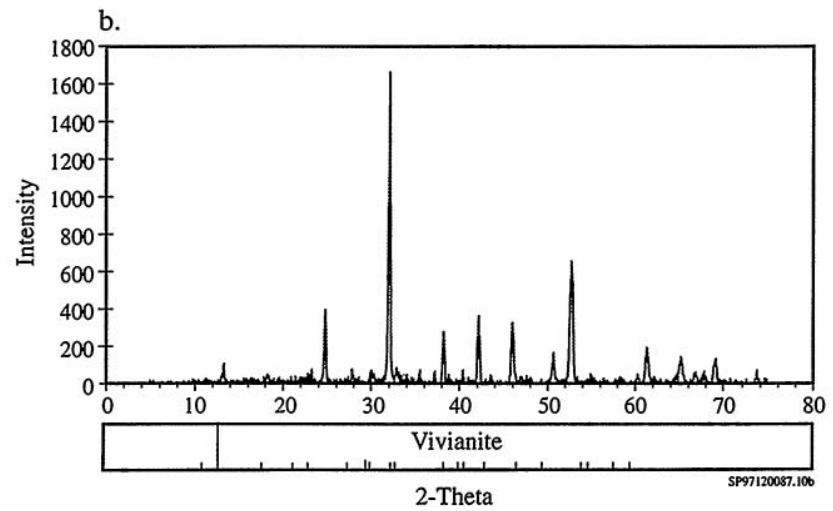

d.

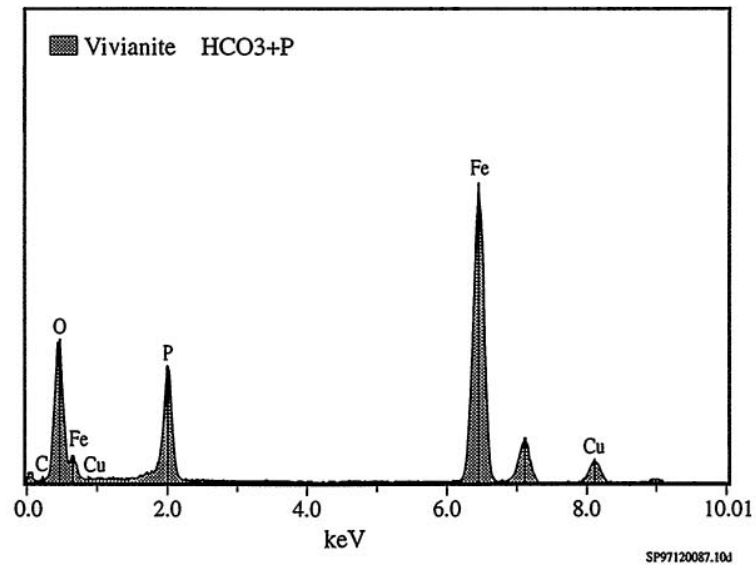

Fig. 10. X-ray diffractograms of microbially reduced Fe solids in bicarbonated-buffered solutions with $\mathrm{PO}_{4}$ and AQDS (a) and with $\mathrm{PO}_{4}$ but no AQDS (b); SEM image of solids from (a) displaying cauliflower-like aggregates; and composition of prismatic pinnacoid crystals in (c) as determined by EDS (d).

to decreased extraction efficiency because of the slower dissolution rate and lower solubility of magnetite in this acid. The $0.5 \mathrm{~N} \mathrm{HCl}$ extraction was effective, however, in dissolving most of the solid associated $\mathrm{Fe}$ (II) except in the singular case where highly crystalline magnetite was the reduction product (medium with PIPES and AQDS). Mass balance calculations using $\mathrm{HCl}$ extractable $\mathrm{Fe}$ values are shown in Table 3.

\section{DISCUSSION}

S. putrefaciens strain $\mathrm{CN} 32$, under conditions promoting oxidation of lactate coupled to respiration of Fe(III), transformed Fe(III) as HFO to distinct phases. The macroscopic reaction sequence is approximated as follows.

\subsubsection{Lactate oxidation}

$4 \mathrm{Fe}(\mathrm{OH})_{3}+\mathrm{CH}_{3} \mathrm{CHOHCOO}^{-}+7 \mathrm{H}^{+}=4 \mathrm{Fe}^{2+}+\mathrm{CH}_{3} \mathrm{COO}^{-}$

$$
+\mathrm{HCO}_{3}^{-}+10 \mathrm{H}_{2} \mathrm{O}(\log \mathrm{K}=58.2)
$$

\subsubsection{HFO phase conversion}

$$
\begin{gathered}
2 \mathrm{Fe}(\mathrm{OH})_{3}+\mathrm{Fe}^{2+}=\mathrm{Fe}_{3} \mathrm{O}_{4}+2 \mathrm{H}_{2} \mathrm{O}+2 \mathrm{H}^{+} \\
2 \mathrm{Fe}(\mathrm{OH})_{3}+4 \mathrm{Fe}^{2+}+\mathrm{A}^{2-}\left(\mathrm{CO}_{3}^{2-}, \mathrm{SO}_{4}^{2-}\right)+9 \mathrm{H}_{2} \mathrm{O} \\
=\left[\mathrm{Fe}_{4}{ }^{I I} \mathrm{Fe}_{2}{ }^{I I I}(\mathrm{OH})_{12}\right]\left[\mathrm{A}^{2-} \cdot 3 \mathrm{H}_{2} \mathrm{O}\right]+6 \mathrm{H}^{+}
\end{gathered}
$$

$$
\begin{gathered}
\mathrm{Fe}^{2+}+\mathrm{HCO}_{3}^{-}=\mathrm{FeCO}_{3}+\mathrm{H}^{+} \\
3 \mathrm{Fe}^{2+}+2 \mathrm{HPO}_{4}^{2-}+8 \mathrm{H}_{2} \mathrm{O}=\mathrm{Fe}_{3}\left(\mathrm{PO}_{4}\right)_{2} \cdot 8 \mathrm{H}_{2} \mathrm{O}+2 \mathrm{H}^{+}
\end{gathered}
$$

where $\mathrm{Fe}_{3} \mathrm{O}_{4},\left[\mathrm{Fe}_{4}{ }^{\mathrm{II}} \mathrm{Fe}_{2}{ }^{\mathrm{III}}(\mathrm{OH})_{12}\right]\left[\mathrm{A}^{2-} \cdot 3 \mathrm{H}_{2} \mathrm{O}\right], \mathrm{FeCO}_{3}$, and $\mathrm{Fe}_{3}\left(\mathrm{PO}_{4}\right)_{2} \cdot 8 \mathrm{H}_{2} \mathrm{O}$ in reactions $3,4,5$, and 6 represent magnetite, green rust, siderite, and vivianite, respectively. Reactions 3 and 4 have been written in terms of solid phase conversions of HFO in accordance with the noted strong sorption of $\mathrm{Fe}^{2+}$ to HFO (Fig. 3) and mechanistic considerations to be discussed in 4.2. The biogenic reduction reaction 2 consumes protons (e.g., $7 \mathrm{H}^{+}$) and tends to increase $\mathrm{pH}$ in the absence of a strong buffer. The subsequent precipitation reactions 3-6, however, tend to liberate protons compensating, in part, for the $\mathrm{pH}$ increase.

\subsection{Microbial Metabolism and HFO Reduction}

Bicarbonate, via its ability to complex $\mathrm{Fe}(\mathrm{II})$ and precipitate as siderite, promoted microbial oxidation of lactate when coupled to dissimilatory reduction of HFO, regardless of whether AQDS or $\mathrm{P}$ were present whereas in PIPES buffer, HFO reduction was less extensive. Although these studies were conducted with synthetic HFO, similar experiments with naturally occurring iron oxides indicates that the natural oxides are equally or more susceptible to microbial reduction (Zachara et al., 1998). Also, the aqueous chemical composition influenced 

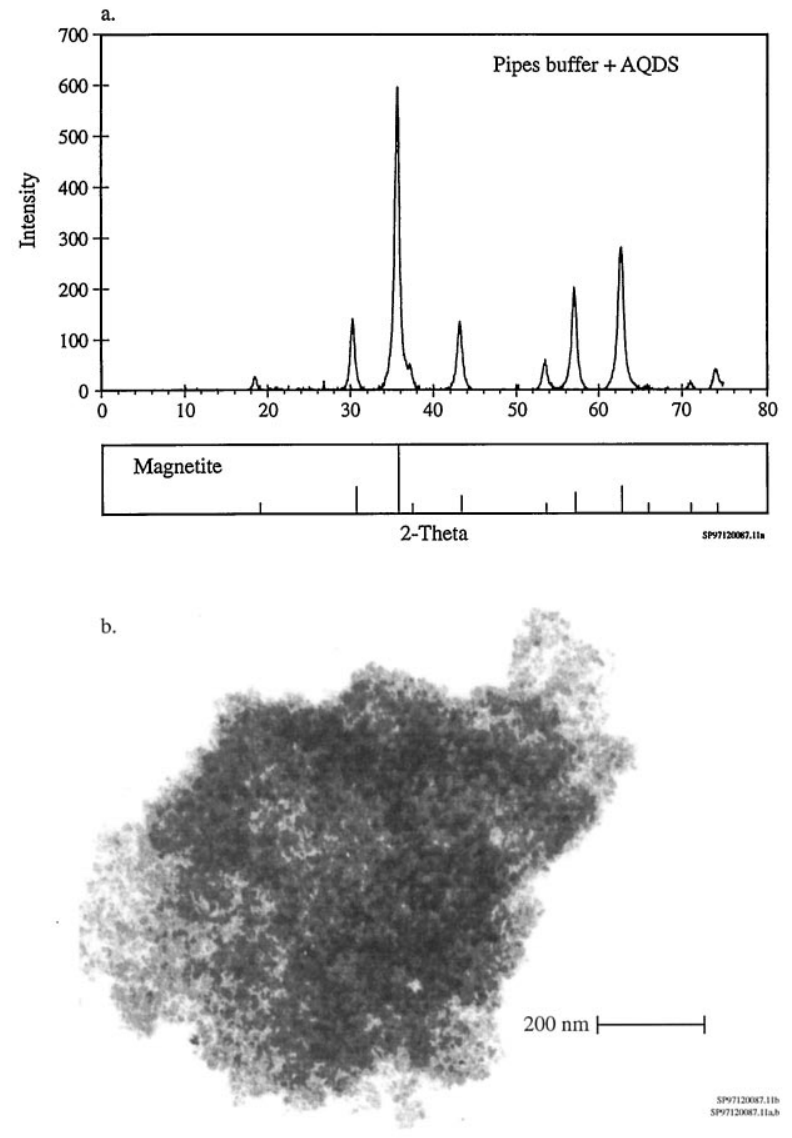

Fig. 11. X-ray diffractogram of microbially reduced solids in PIPESbuffered solutions with AQDS (a) and TEM image of Fe solids (b).

the extent of reduction of the natural oxides and distribution of the resulting $\mathrm{Fe}$ (II) in a manner similar to that observed in this study. The variations in the extent of metabolism as a function of medium composition were evidenced by the differences in the concentration of HCl-extractable Fe(II) (Figs. 1a and b, 4a, $5 \mathrm{a}$ and $\mathrm{b}$ and Table 3 ) and from acetate generated as a result of lactate oxidation (Table 4). Greater than $84 \%$ of the HFO was reduced in the various bicarbonate buffered solutions. In contrast, only $32-52 \%$ of the HFO was reduced in the PIPES buffer in the absence of $\mathrm{P}$ and AQDS; the phase formed was predominantly magnetite. When P and AQDS were present in PIPES, the extent of HFO reduction was significantly greater $(>70 \%)$, and the resulting solid phase was predominantly green rust.

$S$. putrefaciens couples the oxidation of lactate to acetate and $\mathrm{CO}_{2}$ with the concomitant reduction of $\mathrm{Fe}(\mathrm{III})$ to $\mathrm{Fe}(\mathrm{II})$ (Eqn. 2 ). The concentrations of lactate (not shown; the moles of lactate consumed were equivalent to the moles of acetate produced) and acetate (Table 4) were quantified as a measure of the extent of metabolism. The highest concentrations of acetate, and, therefore, the greatest extent of metabolism of lactate, occurred in media where P and AQDS were present. Phosphorous consistently stimulated the oxidation of lactate in comparison to those solutions where it was absent (Table 4). It is well known that $\mathrm{P}$ is a growth-limiting nutrient for microorganisms and is a constituent of macromolecules such as nucleic acids, nucleotides, and phospholipids. Although the cell populations did not change significantly over the course of the experiments in any of the treatments, there may have been growth in those treatments with added $\mathrm{P}$ balanced against cell death. However, the method used for measuring cell population size (direct microscopic counting) does not distinguish viable from nonviable cells or recently grown cells from those added as part of the inoculum. Even in the absence of cell turnover and growth, the presence of $\mathrm{P}$ could have promoted the biosynthesis of cell components such as lipopolysaccharide (LPS) and exopolysaccharide (EPS). Gram-negative bacteria such as $S$. putrefaciens typically contain an outer layer of LPS that has a high affinity for divalent metal cations, primarily due to the phosphoryl constituents (Ferris, 1989). Hence, in addition to abiotic effects, the presence of $\mathrm{P}$, via stimulation of cell biosynthesis and general enhancement of metabolism, could have facilitated lactate oxidation and HFO reduction by $S$. putrefaciens $\mathrm{CN} 32$. The role of AQDS on microbial metabolism and Fe reduction is discussed further in section 4.3.

The formation of magnetite and more reduced mineral assemblages including vivianite, siderite, and green rust have significant implications for microbial metabolism in sediments. The formation of magnetite during microbial reduction of HFO sequesters two-thirds of the Fe(III) from the bioavailable pool. Subsequently, this will function to constrain microbial metabolism that is dependent upon Fe(III) respiration. Therefore, an understanding of the chemical and biological factors and mechanisms controlling the formation of magnetite and the subsequent tranformation of magnetite to more reduced phases is essential for predicting or controlling microbial iron respiration.

Because of the potentially incomplete recovery of magnetite $\mathrm{Fe}$ (II) by the $0.5 \mathrm{~N} \mathrm{HCl}$ extraction (Table 3, expt. 2), a more concentrated acid $(3 \mathrm{~N} \mathrm{HCl})$ extraction was employed in the third experiment. The $3 \mathrm{~N} \mathrm{HCl}$ extraction resulted in a more complete recovery of $\mathrm{Fe}$, especially for the PIPES-buffered medium (Table 3). However, the masses of Fe(II) extracted by the strong acid were not significantly higher than those extracted by $0.5 \mathrm{~N} \mathrm{HCl}$. This would be expected in those treatments where acid soluble phases such as vivianite and siderite had formed, but not in solutions such as PIPES + AQDS, where highly crystalline magnetite dominated. Magnetite and other crystalline iron oxides such as goethite and hematite are only sparingly soluble in cold, dilute $\mathrm{HCl}$ (Chao and Zhou, 1983). Since the non- $0.5 \mathrm{~N} \mathrm{HCl}$ extractable fraction in the PIPES and PIPES + AQDS treatments were predominantly $\mathrm{Fe}(\mathrm{III})$, it may be that some of the HFO was converted to a more crystalline, hence less acid soluble, form during incubation. Cornell and Schneider (1989) observed the formation of acicular goethite crystallites during the reductive dissolution of HFO by cysteine. Whether AQDS promotes a similar effect is not known. The $3 \mathrm{~N} \mathrm{HCl}$ extractable $\mathrm{Fe}(\mathrm{II})$ and $\mathrm{Fe}(\mathrm{II}+\mathrm{III})$ concentrations were generally consistent with the $\mathrm{Fe}(\mathrm{II}) / \mathrm{Fe}$ (III) stoichiometry of the phases identified by XRD and TEM with SAED and EDS.

\subsection{Secondary Phase Formation Accompanying Reduction}

\subsubsection{Thermodynamic consistency of the phase association}

Under oxic conditions (e.g., pe $>6$ ), HFO is thermodynamically unstable with respect to goethite and hematite. HFO will 


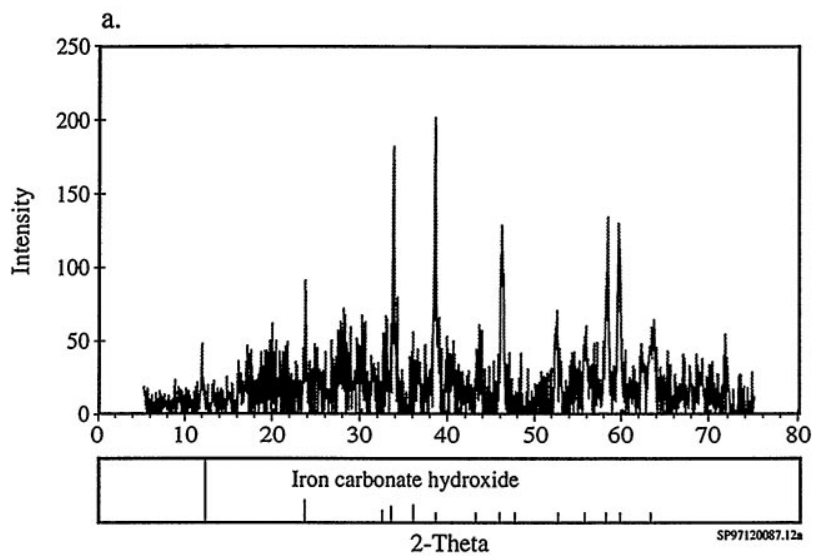

c.

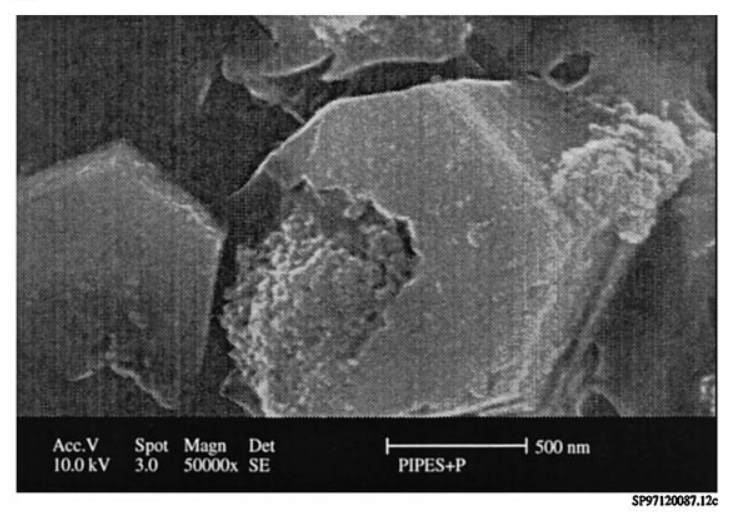

b.

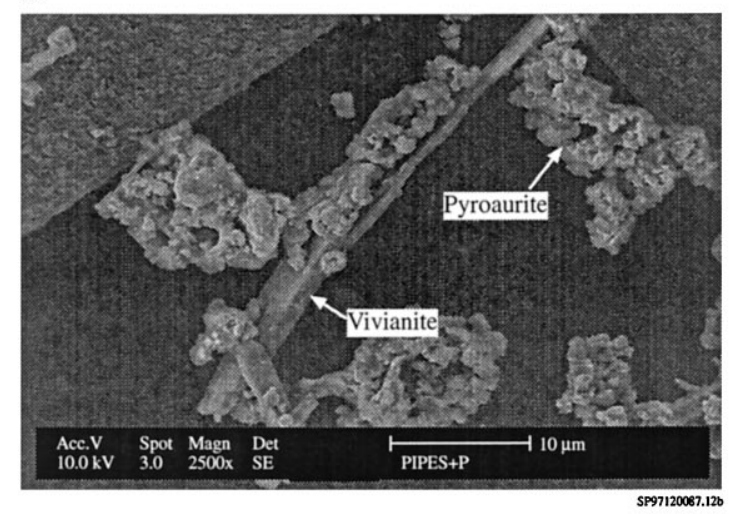

d.

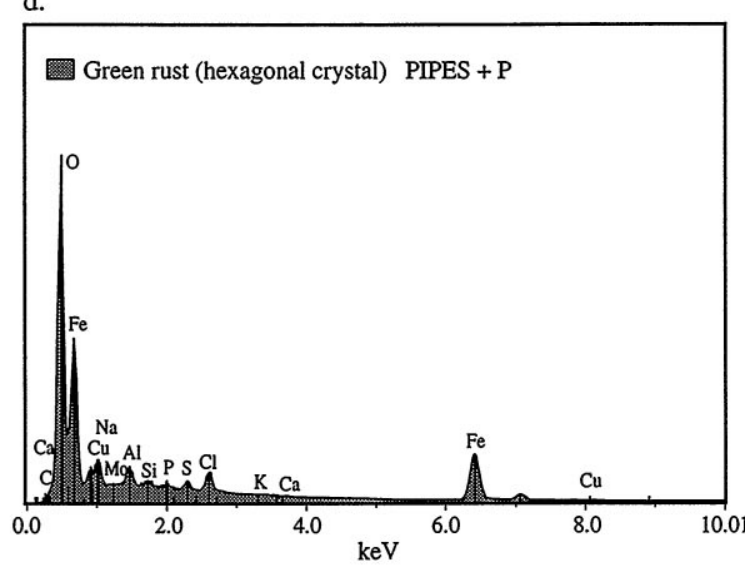

Fig. 12. X-ray diffractogram of microbially reduced solids in PIPES buffer with $\mathrm{PO}_{4}$ and AQDS (a), SEM of solids in this same treatment (b), hexagonal crystal with a minor fine-grained phase (left side) (c) and composition of hexagonal crystal (right side of c) as determined by EDS.

slowly transform to these phases at $25^{\circ} \mathrm{C}$ in hundreds of hours in the absence of sorbates that suppress this transformation (e.g., $\mathrm{PO}_{4}$ and others, Fischer and Schwertmann, 1975; Schwertmann and Murad, 1983; Cornell and Giovanoli, 1985). Certain abiotic reductants, such as cysteine, may promote such crystallization (Cornell and Schneider, 1989). While these crystallization reactions are competitive to the reductive ones stud- ied here and could potentially influence experimental outcome, there was no evidence of crystalline Fe(III)-oxides in any of the control suspensions at experiment termination. These results suggest that the rate of crystalline Fe(III) oxide formation in the solutions used was significantly slower than the biotic reduction reaction.

Using the best available thermodynamic data and the

Table 3. Efficiency of $\mathrm{HCl}$ extractions of microbially reduced solids after incubation for $20 \mathrm{~d}$

\begin{tabular}{|c|c|c|c|c|c|c|c|c|}
\hline \multirow[b]{3}{*}{ Treatment } & \multirow{2}{*}{\multicolumn{2}{|c|}{$\begin{array}{c}\text { Expt. } 2 \\
0.5 \mathrm{~N} \mathrm{HCl}\end{array}$}} & \multicolumn{6}{|c|}{ Expt. 3} \\
\hline & & & \multicolumn{2}{|c|}{$0.5 \mathrm{~N} \mathrm{HCl}$} & \multicolumn{2}{|c|}{$3 N \mathrm{HCl}$} & \multicolumn{2}{|c|}{$3 N \mathrm{HCl}$ (whole tube) $)^{\mathrm{a}}$} \\
\hline & $\mathrm{Fe}(\mathrm{II})$ & $\mathrm{Fe}(\mathrm{II}+\mathrm{III})$ & $\mathrm{Fe}(\mathrm{II})$ & $\mathrm{Fe}(\mathrm{II}+\mathrm{III})$ & $\mathrm{Fe}(\mathrm{II})$ & $\mathrm{Fe}(\mathrm{II}+\mathrm{III})$ & $\mathrm{Fe}(\mathrm{II})$ & $\mathrm{Fe}(\mathrm{II}+\mathrm{III})$ \\
\hline \multicolumn{9}{|c|}{$-\mathrm{mM}-$} \\
\hline$\# 1\left(\mathrm{HCO}_{3}+\mathrm{P}+\mathrm{AQDS}\right)$ & $37.6(4.8)$ & $39.8(4.6)$ & $38.3(2.5)$ & $39.8(2.2)$ & $41.9(3.1)$ & $45.8(4.6)$ & 50.2 & 49.1 \\
\hline$\# 3\left(\mathrm{HCO}_{3}+\mathrm{AQDS}\right)$ & $40.1(0.6)^{\mathrm{c}}$ & $44.3(0.7)$ & $40.7(2.0)$ & $45.3(2.4)$ & $44.2(0.5)$ & $49.9(0.8)$ & 43.5 & 47.0 \\
\hline$\# 4\left(\mathrm{HCO}_{3}\right)$ & $\mathrm{nd}^{\mathrm{b}}$ & nd & $46.3(5.7)$ & $52.0(3.6)$ & $43.5(4.7)$ & $51.7(4)$. & 49.2 & 50.7 \\
\hline \#5 (PIPES + P + AQDS) & $28.1(1.6)$ & $38.8(0.7)$ & $47.6(1.5)$ & $61.6(2.1)$ & $40.6(2.6)$ & $57.7(6.4)$ & 41.4 & 51.7 \\
\hline \#7 (PIPES + AQDS) & $16.1(0.8)$ & $39.0(1.6)$ & $22.6(0.9)$ & $23.4(0.9)$ & $25.8(0.6)$ & $54.7(0.9)$ & 25.6 & 45.4 \\
\hline \#8 (PIPES) & nd & nd & $14.2(0.7)$ & $15.0(0.8)$ & $16.8(0.9)$ & $52.8(3.6)$ & 17.5 & 49.5 \\
\hline
\end{tabular}

${ }^{a}$ Due to plating of precipitates on the sides of some of the tubes, a single whole tube from each treatment was also extracted with $3 \mathrm{~N} \mathrm{HCl}$.

${ }^{\mathrm{b}}$ nd $=$ not determined.

${ }^{\mathrm{c}}$ Values in parentheses are standard errors. 
Table 4. Stoichiometry of acetate and Fe(II) production in CN32 cultures with amorphous Fe oxide as the electron acceptor and lactate as the electron donor

\begin{tabular}{|c|c|c|c|c|}
\hline Buffer & $\begin{array}{c}\text { Solution } \\
\text { composition }\end{array}$ & $\begin{array}{c}\text { Acetate produced } \\
(\mathrm{mM})\end{array}$ & $\begin{array}{l}\mathrm{Fe}(\mathrm{II}) \text { produced }^{\mathrm{a}} \\
(\mathrm{mM})\end{array}$ & $\begin{array}{l}\% \text { of theoretical } \\
\text { maximum }^{c}\end{array}$ \\
\hline $\mathrm{HCO}_{3}$ & $\mathrm{P}, \mathrm{AQDS}$ & $11.49(0.09)^{\mathrm{b}}$ & $33.68(3.41)$ & 73 \\
\hline $\mathrm{HCO}_{3}$ & $\mathrm{P}$ & $10.73(0.11)$ & $27.68(1.94)$ & 65 \\
\hline $\mathrm{HCO}_{3}$ & AQDS & $9.55(0.87)$ & $21.71(5.41)$ & 57 \\
\hline $\mathrm{HCO}_{3}$ & Unamended & $7.66(0.78)$ & $15.63(5.77)$ & 51 \\
\hline PIPES & $\mathrm{P}, \mathrm{AQDS}$ & $8.08(1.82)$ & $33.39(2.60)$ & 103 \\
\hline PIPES & $\mathrm{P}$ & $4.76(0.08)$ & $13.08(1.44)$ & 69 \\
\hline PIPES & AQDS & $3.43(0.27)$ & $5.77(0.62)$ & 42 \\
\hline PIPES & Unamended & $2.60(0.01)$ & $3.58(0.29)$ & 34 \\
\hline $\mathrm{HCO}_{3}$ (autoclaved $\mathrm{Fe}$ ) & $\mathrm{P}, \mathrm{AQDS}$ & $12.62(0.11)$ & $42.44(3.16)$ & 84 \\
\hline $\mathrm{HCO}_{3}$ (autoclaved $\left.\mathrm{Fe}\right)$ & $\mathrm{P}$ & $6.81(0.51)$ & $23.48(7.38)$ & 86 \\
\hline PIPES (autoclaved Fe) & $\mathrm{P}, \mathrm{AQDS}$ & $7.87(1.01)$ & $26.10(2.28)$ & 83 \\
\hline PIPES (autoclaved Fe) & $\mathrm{P}$ & $4.10(0.74)$ & $13.11(0.76)$ & 80 \\
\hline \multicolumn{5}{|c|}{ Repeat } \\
\hline $\mathrm{HCO}_{3}$ & $\mathrm{P}, \mathrm{AQDS}$ & $13.05(0.84)$ & $37.65(4.84)$ & 72 \\
\hline $\mathrm{HCO}_{3}$ & AQDS & $12.26(2.11)$ & $40.11(0.57)$ & 82 \\
\hline PIPES & $\mathrm{P}, \mathrm{AQDS}$ & $10.91(0.63)$ & $28.12(1.58)$ & 64 \\
\hline PIPES & AQDS & $7.24(1.25)$ & $16.08(0.84)$ & 56 \\
\hline
\end{tabular}

${ }^{a} \mathrm{Fe}(\mathrm{II})$ extracted by $0.5 \mathrm{~N} \mathrm{HCl}$.

${ }^{\mathrm{b}}$ Standard error of the mean in parentheses.

${ }^{\mathrm{c}}$ The theoretical stoichiometry of lactate oxidation to acetate and $\mathrm{CO}_{2}$ coupled to $\mathrm{Fe}(\mathrm{II})$ reduction is 1:4 for lactate and $\mathrm{Fe}$ (II), respectively..

specific chemical composition of the media, we have computed the stable phase associations as a function of pe in the two buffer systems, PIPES (Fig. 13a,b ) and bicarbonate (Fig. 13c,d). For these calculations, magnetite, siderite, and vivianite were allowed to precipitate in the two buffer solutions as a function of pe with $50 \mathrm{mM} \mathrm{HFO}$ as the initial solid. Aqueous complexation equilibria of acetate, carbonate, phosphate, and sulfate were considered. The average
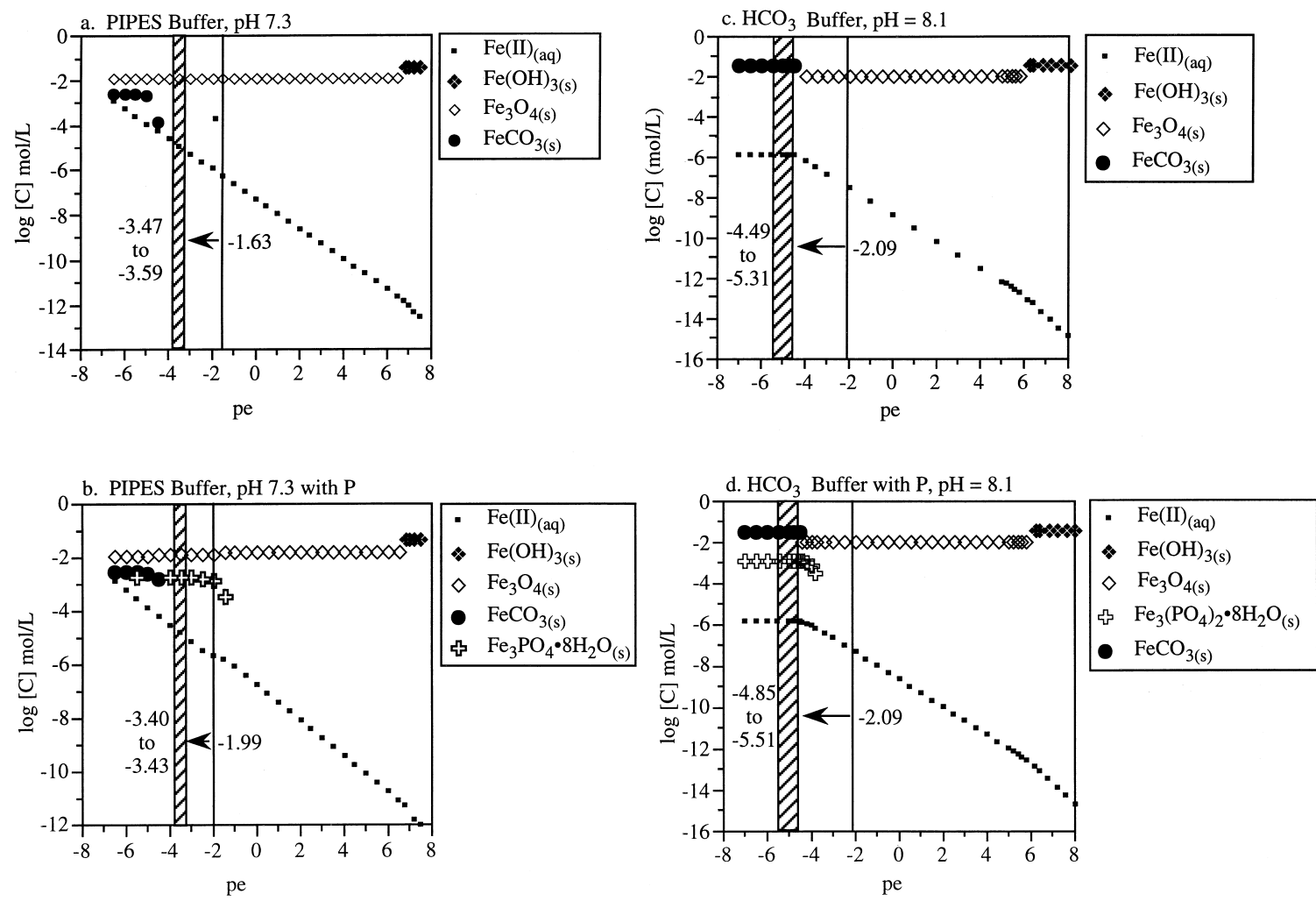

Fig. 13. Computed solid phase stability as a function of pe in PIPES buffer at pH 7.3. Without P (a) and with P (b). Computed solid phase stability as a function of pe in $\mathrm{HCO}_{3}$ buffer at $\mathrm{pH}$ 8.1. Without $\mathrm{P}(\mathrm{c})$ and with $\mathrm{P}(\mathrm{d})$. Starting and ending experimental pe as determined from AQDS measurement is noted. 
final $\mathrm{pH}$ of the two buffers was used (PIPES $=7.3, \mathrm{HCO}_{3}=$ 8.1). The calculation did not consider the reductive energetics of lactate, only its complexation of $\mathrm{Fe}^{2+}$. Green rust was not considered because of the compositional and thermodynamic uncertainties.

Considering the HFO as the stable Fe(III)-oxide at experiment initiation (as opposed to goethite or hematite) for purposes of discussion, our measurements of AQDS speciation in the control suspensions without $\mathrm{CN} 32$ place the initial chemical conditions ( $\mathrm{pe}=-1.63$ to -2.09 ) well within the stability field of magnetite in both buffer systems (Fig. 13). In spite of favorable thermodynamic conditions for abiotic magnetite formation, however, magnetite was not observed in any of the controls at experiment termination. This observation parallels that of Lovley et al. (1991), that nonenzymatic reduction of $\mathrm{Fe}(\mathrm{III})$ oxides, including HFO, proceeds slowly.

As reductive equivalents were liberated from lactate via respiration, they were transferred to the $\mathrm{HFO}$, initiating its rapid reduction (Eqn. 2) and mineralogic transformation (Eqn. $3-6)$. Respiration was indicated by the accumulation of acetate, reduction of $\mathrm{Fe}(\mathrm{III})$, and the lowering of pe by 1.75 to over 3 log units as indicated by AQDS speciation (shown on Fig. 13). In PIPES buffer with and without $\mathrm{P}$, the geochemical conditions remained within the magnetite stability field during the course of biotic reduction. Consistent with thermodynamics (Fig. 13c), the mineralogic product in the PIPES/AQDS without $\mathrm{P}$ treatment was magnetite (Fig. 11). When $\mathrm{P}$ was present, however, we observed green rust formation (Fig. 12) rather than the predicted phase assemblage of magnetite and vivianite (Fig. 13b). Magnetite formation may have been inhibited by phosphate, as discussed below. For the bicarbonate system, the geochemical conditions evolved from those within the magnetite stability field (pe $=-2.09$ ) to those immediately below the phase transition point $(\mathrm{pe}=-4.4$ ) where siderite and vivianite (when $\mathrm{P}$ was present) were the stable phases. Indeed, the pe should not drop significantly below this level because the electron acceptor [Fe(III)] is fully reduced. The mineralogy of the biogenic solids in the bicarbonate buffer was consistent with a reaction path through the magnetite stability field, e.g., fine-grained magnetite was observed as a minor accessory phase with siderite in the bicarbonate buffer with AQDS.

\subsubsection{Thermodynamic constraints on reduction}

Important to this study are the reasons for the complete reduction of $\mathrm{HFO}$ to $\mathrm{Fe}$ (II) (as siderite or siderite/vivianite) in the bicarbonate buffer and its incomplete reduction to green rust and magnetite in the PIPES buffer. In the PIPES buffer, a mass balance of lactate shows that greater than $75 \%$ of its initial concentration still remains at experiment termination. Why then did reduction cease after the formation of magnetite (in the PIPES/AQDS system), leaving $60 \%$ of the Fe(III) when excess electron donor was still present? The fact that HFO was fully reduced to $\mathrm{Fe}$ (II) in the bicarbonate system indicates that sufficient electron equivalents existed in the lactate to do so. The answer to this question lies, in part, in reaction thermodynamics.

While magnetite has often been considered a terminal product in dissimilatory Fe(III)-oxide reduction (Lovley, 1991b), Kostka and Nealson (1995) argued that its apparent recalci- trance to microbiological reduction at circumneutral $\mathrm{pH}$ results from unfavorable thermodynamics. Their experiments showed that magnetite was reducible by $S$. putrefaciens when the initial media $\mathrm{pH}$ ranged from values of $\mathrm{pH} 5-6.5$ where the reaction was predicted to be thermodynamically feasible. These $\mathrm{pH}$ values were below those used in our experiments and below those observed at experiment termination.

We performed a thermodynamic assessment to ascertain whether energy was still available for reduction of magnetite at the termination of the PIPES/AQDS experiment where well crystallized magnetite was observed as the only, and apparently terminal, mineralogic product of reduction (e.g., Fig. 11). The analysis was based on the following reaction where thermodynamic data was taken from Morel (1983):

$$
\begin{aligned}
2 \mathrm{Fe}_{3} \mathrm{O}_{4}+\mathrm{CH}_{3} \mathrm{CHOHCOO}^{-} & +11 \mathrm{H}^{+}=6 \mathrm{Fe}^{2+}+\mathrm{CH}_{3} \mathrm{COO}^{-} \\
+ & \mathrm{HCO}_{3}^{-}+6 \mathrm{H}_{2} \mathrm{O}(\log \mathrm{K}=60.6)
\end{aligned}
$$

The equilibrium activity quotient (EAQ) so defined is:

$\left\{\mathrm{CH}_{3} \mathrm{COO}^{-}\right\}\left\{\mathrm{HCO}_{3}^{-}\right\}\left\{\mathrm{Fe}^{2+}\right\}^{6} /\left\{\mathrm{CH}_{3} \mathrm{CHOHCOO}^{-}\right\}\left[\mathrm{Fe}_{3} \mathrm{O}_{4}\right]^{2}\left\{\mathrm{H}^{+}\right\}^{11}$

$$
=10^{60.6}(8)
$$

where \{\} denotes activities and [ ] concentration, respectively. Activities for the chemical species in Eqn. 6 for the PIPES/ AQDS experiment were calculated from the final concentration data in Table 3, taking full account of ionic strength and aqueous complexation effects. The activity quotient (AQ) so obtained $\left(10^{60.6}\right)$ was in remarkable agreement with the equilibrium value $(\mathrm{AQ} / \mathrm{EAQ} \approx 1)$. While the close agreement was likely fortuitous, the result suggests that $\Delta \mathrm{G} \approx 0$ and that there was little or no chemical energy remaining at experiment termination to drive further reduction of $\mathrm{Fe}(\mathrm{III})$ in the magnetite. We note, however, the large dependence of the AQ on $\left\{\mathrm{Fe}^{2+}\right\}$ and $\left\{\mathrm{H}^{+}\right\}$and are cautious not overemphasize this finding given the experimental uncertainty in the measurement and thermodynamic estimation of both these parameters. These findings are consistent with those of Kostka and Nealson (1995) who argued that the microbial reduction of magnetite should be dependent of $\mathrm{pH}$ and $\left[\mathrm{Fe}^{2+}\right]_{\mathrm{aq}}$. One additional observation was curious. We numerically allowed the solution data used for this calculation in Table 2, which was supersaturated with respect to magnetite (Table 2, Section 3.5), to react to equilibrium. The resulting $\left[\mathrm{Fe}_{(\mathrm{aq})}^{2+}\right]_{\mathrm{TOT}}$ changed from $1.95 \times 10^{-3} \mathrm{~mol} / \mathrm{L}$ to $1.53 \times 10^{-5} \mathrm{~mol} / \mathrm{L}$. The AQ/EAQ ratio that was calculated using the equilibrium $\mathrm{Fe}^{2+}$ activity was $\ll 1$, signifying that there was potential chemical energy remaining in lactate to drive magnetite reduction. It may, therefore, be plausible that the excess $\mathrm{Fe}^{2+}$ observed in this suspension (above solubility equilibrium) was due to bacterial reduction of magnetite which ceased as chemical energy was exhausted.

The presence of high carbonate in the aqueous phase and a large reservoir of $\mathrm{CO}_{2(\mathrm{~g})}$ to maintain that aqueous concentration were important factors allowing the complete reduction of HFO in the bicarbonate buffer. Thermodynamic analysis indicates that siderite formation in the bicarbonate buffer can energetically drive the microbial reductive dissolution of magnetite by lactate at circumneutral $\mathrm{pH}$ and above, through the maintenance of a low aqueous activity of $\mathrm{Fe}^{2+}$. Thus, the bicarbonate buffer provides a more favorable energetic environment than PIPES 
for Eqns. 2 and 8 to proceed to the right and completion. It is not known whether magnetite was initially formed in the bicarbonate buffer with subsequent biotic reduction to siderite or whether siderite was the initial reaction product. Vivianite maintains an even lower $\mathrm{Fe}^{2+}$ activity than does siderite in the bicarbonate buffer and, for that reason, it also thermodynamically promotes the reduction of magnetite. The overall impact of vivianite formation is limited, however, by the fact that the total $\mathrm{P}$ concentration $(4 \mathrm{mM})$ is ten-fold below that of $\mathrm{Fe}(\mathrm{III})$.

\subsubsection{Implications for formation mechanism}

As shown above, the crystalline solids observed as primary reduction products (magnetite, siderite, vivianite) exhibit thermodynamic consistency. The observation that HFO in controls does not transform to magnetite and that secondary mineralization is rapid and parallels respiration, however, suggests a microbial role in mineral synthesis. Magnetite, siderite, and green rust, however, have all been observed as abiotic reaction products formed under chemical conditions similar to those used here. At issue is whether the microbial role in the synthesis of these phases reported herein has been direct or indirect.

Magnetite forms rapidly at circumneutral $\mathrm{pH}$ and higher in periods of hours (e.g., 3-12 h) by topotactic/solid state conversion of HFO following $\mathrm{Fe}_{(\mathrm{aq})}^{2+}$ sorption (Cornell, 1988; Mann et al., 1988; Tronc et al., 1992). The magnetite so formed is fine grained and similar in size and appearance (Tronc et al., 1992) to the magnetite observed herein. Typically, magnetite is the sole reaction product if the $\mathrm{Fe}(\mathrm{II}) / \mathrm{Fe}$ (III) ratio is low (i.e., $<0.5$ ) approximating magnetite Fe stoichiometry, but associated phases including green rust and siderite have been observed if the $\mathrm{Fe}$ (II)/ $\mathrm{Fe}$ (III) ratio becomes higher or if carbonate is present (Taylor, 1980; Mann, 1989). Couling and Mann (1985) reported that the addition of phosphate to HFO prior to $\mathrm{Fe}_{(\mathrm{aq})}^{2+}$ addition retards magnetite formation, undoubtedly via its strong sorption and site blockage. The strong sorption of $\mathrm{Fe}_{(\mathrm{aq})}^{2+}$ to HFO (e.g., Fig. 3) and the absence of significant soluble $\mathrm{Fe}$ (II) during the course of biotic HFO reduction in PIPES + AQDS suggests that this mechanism may have been the operative one here. The absence of well crystallized magnetite in all but the PIPES + AQDS treatment suggests that AQDS mediates the reaction.

As noted by Hansen et al. (1994), green rusts (GR) are readily synthesized in the laboratory by a number of different means. Under appropriate abiotic chemical conditions, GR forms rapidly, yielding crystalline solids with hexagonal morphology in less than $24 \mathrm{~h}$ at $25^{\circ} \mathrm{C}$. Green rust formation is $\mathrm{pH}$ sensitive, with the optimal range falling between $\mathrm{pH}$ 6.5-7.5. A characteristic abiotic formation mechanism for $\mathrm{GR}$ is by $\mathrm{Fe}_{(\mathrm{aq})}^{2+}$ sorption to HFO at circumneutral $\mathrm{pH}$ and solid state conversion (Mann et al., 1989; Hansen et al., 1994). Anions are required (e.g., $\mathrm{SO}_{4}^{2-}, \mathrm{CO}_{3}^{2-}$ ) that stabilize the hydrotalcite structure via charge compensating intercalation (Brindley and Bisch, 1976). Green rust appears favored over magnetite when the $\mathrm{Fe}(\mathrm{II}) /$ $\mathrm{Fe}$ (III) ratio exceeds 2 or more. Green rust is known as a transitory phase in the corrosion/oxidation of steel (Stampfl, 1969; Bigham and Tuovinen, 1985) and is a reduced precursor to the oxidative formation of magnetite (Tamaura et al., 1984) and other crystalline Fe(III) oxides. The identification of GR in geologic materials has been difficult because of their oxidative lability, but several examples exist (Koch and Morup, 1991; Trolard et al., 1997).

To our knowledge, ours is the first report of biotic GR formation. The most plausible biotic formation mechanism is the solid state conversion of HFO, paralleling the abiotic synthesis procedures noted above (Mann et al., 1989; Hansen et al., 1994). Magnetite formation is apparently inhibited initially by $\mathrm{P}$ sorption to the HFO, and this, and other undefined factors, apparently allow the biotic generation of a $\mathrm{Fe}(\mathrm{II}) / \mathrm{Fe}$ (III) ratio large enough for GR formation. GR may be thermodynamically more stable than magnetite under the specific experimental/ media conditions. Based upon EDS spectra, we propose that the biotic compound is a mixed $\mathrm{SO}_{4}^{2-} / \mathrm{CO}_{3}^{2-}$ green rust, with the interlayer carbonate arising from respiration. Phosphate is also a plausible interlayer anion, but the observed presence of vivianite, in association with the GR, suggests that much of the P is associated with that phase.

$\mathrm{Mg} / \mathrm{Al}$-hydrotalcites show preference for $\mathrm{CO}_{3}^{2-}$ over $\mathrm{SO}_{4}^{2-}$ (Miyata, 1983), and if such behavior holds here, the GR may be closer to the pure hydroxycarbonate endmember (Taylor et al., 1985). Indeed, the X-ray diffraction spectra for the biogenic GR shows closest agreement to that reported for iron carbonate hydroxide (Fig. 12). Mass balance on carbonate (respiratory $\mathrm{C}_{\mathrm{T}}$ estimated from the acetate analysis $[8.08 \mathrm{mM}]$ - analytical DIC [4.5 mM]) indicates that as much as $3.58 \mathrm{mM}$ of respiratory $\mathrm{CO}_{3}^{2-}$ is associated with the GR (using Eqn. 4 stoichiometry) as an interlayer anion. The remaining estimated positive charge (2.92 $\mathrm{mM}$ ) is apparently compensated by a combination of $\mathrm{SO}_{4}^{2-}, \mathrm{HPO}_{4}^{2-}$, and possibly $\mathrm{Cl}^{-}$as suggested by the EDS analysis. As noted for magnetite, AQDS mediates the GR formation reaction as GR is not observed in the absence of AQDS.

Siderite is a frequently observed diagenetic precipitate in recent aquatic and geologic sediments (Postma, 1981; Gautier, 1982; Pye et al., 1990; Mozley and Carothers, 1992; Mortimer et al., 1997). Its formation is generally associated with the bacterial respiration of organic matter coupled with dissimilatory iron reduction (Suess, 1979; Pye et al., 1990); although the in situ geochemical conditions under which siderite forms are not well established (Pye et al., 1990). The stable isotopic signature of sedimentary siderite typically indicates significant disequilibrium (Mortimer and Coleman, 1997), which in turn, has been used to speculate on the conditions of its formation (Mozley and Wersin, 1992; Pye et al., 1990). High alkalinity and $\mathrm{Fe}_{(\mathrm{aq})}^{2+}$, as promoted by bacterial activity, seem important to its precipitation (Rajan et al., 1996; Mortimer and Coleman, 1997). While the free energy and enthalpy of siderite are relatively well established through investigations of hydrothermally synthesized material (Wersin et al., 1989; Bruno et al., 1992; Chai and Navrotsky, 1994); little appears to be known about abiotic formation mechanisms and kinetics under temperature and pressure conditions relevant to this study. Lippmann (1973) notes that siderite forms artificially at room temperature from solutions with high supersaturation and that the formation rates are sluggish and the products are of poor crystallinity. One example of abiotically precipitated siderite at $33^{\circ} \mathrm{C}$ was different from the biogenic forms observed here (Carothers et al., 1988); it was comprised of small $(<0.5 \mu \mathrm{m})$ psuedo-cubic crystallites that were aggregated in approximate 6-8 $\mu \mathrm{m}$ spheres. 


\subsection{Role of AQDS and Implications for Biomineralization}

The inclusion of the humic acid analog AQDS at $100 \mu \mathrm{M}$ enhanced the rate and extent of HFO reduction by CN32 (Fig. 5), and, presumably, the overall respiration rate. Additionally, significant differences in the mineralogic products of reduction were observed in the presence and absence of AQDS. These differences were greatest in PIPES buffer where the reduction rate enhancement was largest. In bicarbonate solutions, AQDS appeared to enhance the crystallinity of the siderite and vivianite products that also formed in its absence. In PIPES buffered solutions, AQDS promoted formation of well crystallized magnetite in the absence of $\mathrm{P}$ and green rust with $\mathrm{P}$, when primarily amorphous reduction products were observed in its absence. AQDS may promote these striking effects by replacing the organism electron transfer system as the de-facto reductive ligand at the oxide surface and functioning as a more accessible electron acceptor that stimulates respiration and allows formation of microenvironments near the organisms that are conducive to mineralization.

The current paradigm for the reduction of Fe(III) oxides by DIRB requires direct contact between cell surfaces and oxides. However, the mechanism(s) by which $S$. putrefaciens achieves electron transfer to the solid phase is unknown. The solubility of HFO at circumneutral $\mathrm{pH}$ is low $\left(10^{-17} \mathrm{Fe}^{3+}\right.$ activity), and is well below the concentration range of $10^{-8}$ to $10^{-6} \mathrm{M}$ required for optimal growth of microorganisms (Guerinot, 1994). Therefore, oxide-reducing bacteria must have mechanisms by which they can transfer electrons from the terminal point of the electron transport chain to the Fe(III) metal ion centers on the oxide surface.

$S$. putrefaciens may achieve electron transfer to HFO in several ways. Some bacteria assimilate iron via high affinity $\mathrm{Fe}$ (III) uptake systems such as siderophores, or nonspecific low-affinity systems involving citrate, malate, or other organic acids. Many gram-negative bacteria have outer membrane receptor proteins that are involved in energy-dependent transport of siderophore-complexed $\mathrm{Fe}(\mathrm{III})$ across the outer membrane for subsequent interaction with periplasmic electron transfer proteins. This mechanism, however, is not likely involved in dissimilatory metal reduction by DIRB because higher concentrations of $\mathrm{Fe}(\mathrm{III})$ are required for energy generation than the high affinity assimilatory systems typically provide. S. putrefaciens localizes $c$-type cytochromes, that are oxidized by $\mathrm{Fe}(\mathrm{III})$ and $\mathrm{Mn}(\mathrm{III})$, to its outer membrane in response to anaerobic growth with fumarate (Myers and Myers, 1992, 1997). These outer membrane cytochromes may participate in electron transfer to oxide surface sites by either direct coordination or through linkages to coassociated electron-transducing proteins.

In spite of mechanistic uncertainty, there is little doubt that biotic electron transfer is constrained by the chemistry and structure of the organism-oxide contact (Roden and Zachara, 1996). AQDS apparently relieves these constraints by its direct interactions with and its ability to shuttle electrons between oxide and cell surfaces. Hydroquinone is a facile reductant of Mn(IV) oxides (Stone and Morgan, 1984; Kung and McBride, 1988). Hydroquinone can reduce ferrihydrite but, for thermodynamic reasons, is weakly reactive toward hematite and goethite (Kung and McBride 1988; LaKind and Stone, 1989). In contrast to hydroquinone, reduced AQDS $\left(\mathrm{AH}_{2} \mathrm{DS}\right)$ is a stronger reductant because of its lower $\mathrm{E}^{\circ}(0.228 \mathrm{~V}$ as compared to that of $0.699 \mathrm{~V}$ for hydroquinone). Hydroquinones form a surface complex on the oxides that allows electron transfer to, and the in-place reduction of, the oxidized metal ion centers on the surface (Stone and Morgan, 1984; Kung and McBride, 1988; LaKind and Stone, 1989). $\mathrm{AH}_{2} \mathrm{DS}$ is structurally similar to hydroquinone and is expected to react with the oxide surface in a similar manner. We suspect that reduced AQDS is more effective in electron delivery to HFO because, as a reactive solute without the structural and size constraints of the organism, it may more readily access the complex surface topography and inter-aggregate space of the amorphic electron acceptor. HFO typically exists in water as loose agglomerates of nanometer size particles where approximately $25 \%$ of the $\mathrm{Fe}$ (III) is solute-reactive (Dzombak and Morel, 1990). $\mathrm{AH}_{2} \mathrm{DS}$ may accelerate topotactic conversion of the HFO by more uniformly reacting with and reducing the $\mathrm{Fe}(\mathrm{III})$ associated with these sites.

Electron micrographs of the solid-microbe interface (not included) show that HFO associates with the organism surface as variable sized aggregates of nanoparticles. The complex geometry of the aggregates and their steric interaction likely prevents optimal interaction between the organism surface and the oxide for electron transfer. A significant percentage of the organism surface does not appear in contact with the oxide under such conditions, and the full reductive potential of the organism surface may not be realized. AQDS may stimulate respiration by providing a greater effective concentration of electron acceptor around the organism periphery. As a solute, it would have improved access to regions of enzymatic activity or high electron density on the organism surface. For this same reason, solutions of $\mathrm{Fe}(\mathrm{III})$-citrate or -nitrilotriacetic acid (NTA) are reduced more rapidly than suspensions of HFO at the same molarity (data not shown). AQDS may also diffuse through the outer membrane to the periplasm where it could engage with the electron transport chain without the need for surface complex formation. AQDS is functionally similar to menaquinones which are integral to the electron transport chain of bacteria including S. putrefaciens (Myers and Myers, 1993), and this similarity may allow AQDS to interact with the electron transport chain by mechanisms that are precluded for the hydroxylated $\mathrm{Fe}$ (III) centers on the oxide surface.

The enhanced respiration of DIRB in the presence of AQDS may favor the development of organism proximate microenvironments. The biogenic mineralization observed herein results from biologically induced as opposed to biologically controlled processes, such as the intracellular membrane-assisted formation of magnetosomes by Aquaspirillum (Gorby et al., 1988). The biomineralization induced by $\mathrm{CN} 32$ may be facilitated by a number of microbially induced chemical effects in addition to $\mathrm{Fe}(\mathrm{III})$ reduction. These effects could include local supersaturation of select ions, complexation, local redox and $\mathrm{pH}$ modifications, changes in ion activities, and the continuous supply of reactants at optimal rates. For example, Eqn. 2 implies that a microenvironment high in $\mathrm{Fe}^{2+}, \mathrm{HCO}_{3}^{-}, \mathrm{CH}_{3} \mathrm{COO}^{-}$, and $\mathrm{pH}$ may surround actively respiring DIRB. Bicarbonate and acetate complexation of $\mathrm{Fe}(\mathrm{II})$ within this microenvironment may draw $\mathrm{Fe}$ (II) from the residue solid phase, and the ensuing elevated concentrations of $\mathrm{Fe}(\mathrm{II})$, hydroxyl, and bicarbonate may pro- 
mote siderite supersaturation and precipitation as postulated by Mortimer and Coleman (1996). In the presence of AQDS, a low pe microenvironment may surround actively respiring cells that is enriched in $\mathrm{AH}_{2} \mathrm{DS}$ and that may destabilize or otherwise prevent the formation of expected solid phases, given the average or macroscopic pe estimated from the global AQDS speciation. The microenvironments may extend beyond the HFO surface into aggregate interstices because the organisms and solid are in close association.

$\mathrm{Fe}$ (II) also sorbs to the surfaces of $S$. alga (Urrutia et al., 1998) and, presumably, to the surfaces of S. putrefaciens. Metal binding to cell surfaces may serve to nucleate or prevent mineralization. Biomineralization can either be enhanced or inhibited by the presence of biological polymers (Williams, 1989) such as LPS, EPS, or protein which are typically associated with the outer surfaces of gram-negative bacteria. The potential impacts of biosorption in this system are not known.

\subsection{IMPLICATIONS FOR IN SITU BIOGEOCHEMICAL PROCESSES}

The extent of HFO reduction by $S$. putrefaciens CN32 was increased by the presence of $\mathrm{Fe}(\mathrm{II})$ complexing ligands such as $\mathrm{HCO}_{3}^{-}$and $\mathrm{HPO}_{4}^{2-}$. Although these studies were conducted with synthetic HFO, similar experiments with naturally occurring iron oxides indicated that the natural oxides were equally or more susceptible to microbial reduction (Zachara et al., 1998). The aqueous chemical composition also influenced the extent of reduction and the distribution of the resulting $\mathrm{Fe}$ (II) in the natural sediments in a manner similar to that observed in this study. In the absence of complexing ligands, as in the PIPES-buffered media, biogenic Fe(II) sorbed strongly to the HFO, promoting its solid-state conversion to magnetite or green rust. These results have significant implications for biomineralization processes involving dissimilatory metal-reducing bacteria in both natural and manipulated environments. Magnetite is an apparent metabolic product of a wide variety of iron-reducing bacteria (Blakemore and Blakemore, 1991; Lovely, 1991b); occurs frequently in soil and aquifer, freshwater, and marine sediments; and is concentrated within ancient banded iron formations (Walker, 1984).

The stability of magnetite in such environments is a function of a number of factors including $\mathrm{pH}$, pe, and $\mathrm{pCO}_{2}$; its presence or absence also reflects geochemical conditions that promote (presence of reactive HFO) or inhibit (presence of high-P) its formation. From a thermodynamic standpoint, magnetite will convert to siderite at atmospheric concentrations of $\mathrm{CO}_{2}$ when the pe $+\mathrm{pH}$ reaches approximately 2.2. Although the microbial reduction of magnetite has been shown to be thermodynamically favorable only under a relatively narrow $\mathrm{pH}$ range, its stability is quite sensitive to the concentration of complexing ions such as $\mathrm{HCO}_{3}$ and $\mathrm{PO}_{4}$. Hence, the microbially directed formation of siderite via reduction of $\mathrm{Fe}$ (III) oxides or magnetite may occur naturally when such ligands and appropriate electron donors are in sufficient concentration.

The weathering of silicates has been postulated to be coupled to the precipitation of carbonates by phototrophic microorganisms, occurring globally on a scale of a billion tonnes of carbonate-C per year (Ferris et al., 1994). Given the abundance of $\mathrm{Fe}$ in anaerobic sedimentary systems, the fixation of $\mathrm{CO}_{2}$ by
$\mathrm{Fe}(\mathrm{II})$ generated by microbial reduction could have an equally significant impact. In addition to $\mathrm{CO}_{2}$ fixation, microbial reduction of $\mathrm{Fe}$ (III) oxides to siderite (or vivianite) or green rust allows for greater oxidation of organic matter or contaminants than when magnetite is the end product. Metal-reducing bacteria can effectively couple the oxidation of organic contaminants to the reduction of Fe(III) (Kazumi et al., 1995; Lovely and Lonergan, 1990). Nitroaromatics (Heijman et al., 1993, 1995) and chlorinated solvents can be abiotically reduced by microbially generated $\mathrm{Fe}$ (II). In aquifer and other sedimentary environments, $\mathrm{Fe}$ (III) and Mn(IV) oxides typically constitute the greatest mass of potential oxidant (Heron et al., 1994); Nealson and Saffarini, 1994). The formation of magnetite in these sediments could effectively sequester two-thirds of the aquifer oxidation capacity to a form that is microbially unavailable and poise the pe at a point where contaminant reduction reactions may be less favorable.

Acknowledgments-This research was supported by the Natural and Accelerated Bioremediation Research Program (NABIR), Office of Biological and Environmental Research, U.S. Department of Energy (DOE). The continued support of Dr. F. J. Wobber is greatly appreciated. Pacific Northwest National Laboratory is operated for the DOE by Battelle Memorial Institute under Contract DE-AC06-76RLO 1830. We thank Dr. David Boone of Portland State Univ. for providing $S$. putrefaciens CN32 to us from the Subsurface Microbial Culture Collection and Dr. Yuri Gorby for helpful discussions. The Subsurface Microbial Culture Collection at Florida State University is supported by DOE Grant No. DE-FG05-90ER61039.

\section{REFERENCES}

Al-Borno A. and Tomson B. T. (1994) The temperature dependence of the solubility product constant of vivianite. Geochim. Cosmochim. Acta 58, 5373-5378.

Allison J. D., Brown D. S., and Novo-Gradac K. J. (1991) MINTEQA2/PRODEFA2, A Geochemical Assessment Model for Environmental Systems: Version 3.0 User's Manual. EPA.

Arnold R. G., DeChristina T. J., Hoffman, M. R. (1988) Reductive dissolution of Fe(III) oxides by Pseudomonas sp. 200. Biotechnol. Bioeng. 32, 1081-1096.

Baedecker M. J., Cozzarelli I. M., Evans J. R., and Hearn P. P. (1992) Authigenic mineral formation in aquifers rich in organic material. In 7th Intl. Conf. Water-Rock Interaction (ed. Kharaka and Maest) pp. 257-261. Balkema.

Bell P. E., Mills A. L., Herman J. S. (1987) Biogeochemical conditions favoring magnetite formation during anaerobic iron reduction. Appl. Environ. Microbiol. 53, 2610-2616.

Bigham J. M. and Tuovinen O. H. (1985) Mineralogical, morphological, and microbiological characteristics of tubercles in cast iron water mains as related to their chemical activity. In Planetary Ecology (ed. D. E. Caldwell et al.), pp. 239-250. Van Nostrand Reinhold.

Blakemore R. P. and Blakemore N. A. (1991) Magnetotactic magnetogens. In Iron Biominerals (ed. R. B. Frankel and R. P. Blakemore), pp. 51-77. Plenum Press.

Brindley G. W. and Bisch D. L. (1976) GR: A pyroaurite type structure. Nature 263, 353.

Bruno J., Wersin P., and Stumm W. (1992) On the influence of carbonate in mineral dissolution: II. The solubility of $\mathrm{FeCO}_{3}(\sigma)$ at $25^{\circ} \mathrm{C}$ and 1 atm total pressure. Geochim. Cosmochim. Acta 56, 1149-1155.

Carothers W. W., Lanford H. A., and Rosenbauer R. J. (1988) Experimental oxygen isotope fractionation between siderite-water and phosphoric acid liberated $\mathrm{CO}_{2}$-siderite. Geochim. Cosmochim. Acta 52, 2445-2450.

Chai L. and Navrotsky A. (1994) Enthalpy of formation of siderite and its application in phase equilibrium calculation. Amer. Mineral. 79, 921-929.

Chao T. T. and Zhou L. (1983) Extraction techniques for selective 
dissolution of amorphous iron oxides from soils and sediments. Soil Sci. Soc. Amer. J. 47, 225-232.

Clark W. M. (1960) Oxidation-Reduction Potentials of Organic Systems. The Williams \& Wilkins Co.

Cornell R. M. (1988) The influence of some divalent cations on the transformation of ferrihydrite into more crystalline products. Clay Mineral. 23, 329-332.

Cornell R. M. and Giovanoli R. (1985) Effect of solution conditions on the proportion and morphology of goethite formed from ferrihydrite. Clays Clay Miner. 33, 424-432.

Cornell R. M. and Schneider W. (1989) Formation of goethite from ferrihydrite at physiological $\mathrm{pH}$ under the influence of cysteine. Polyhedron 8, 149-155.

Couling S. B. and Mann S. (1985) The influence of inorganic phosphate on the crystallization of magnetite $\left(\mathrm{Fe}_{3} \mathrm{O}_{4}\right)$ from aqueous solution. J. Chem. Soc. Chem. Comm. 1713-1715.

Dzombak D. A. and Morel F. M. M. (1990) Surface complexation modeling: Hydrous ferric oxide. Wiley.

Emerson S. (1976) Early diagenesis in anaerobic lake sediments: Chemical equilibria in interstitial waters. Geochim. Cosmochim. Acta 40, 925-934.

Emerson S. and Widmer G. (1978) Early diagenesis in anaerobic lake sediments-II. Thermodynamic and kinetic factors controlling the formation of iron phosphate. Geochim. Cosmochim. Acta 42, 13071316.

Ferris F. G. (1989) Metallic ion interactions with the outer membrane of Gram-negative bacteria. In Metal Ions and Bacteria (ed. T. J. Beveridge and R. J. Doyle), pp. 295-323. Wiley.

Ferris F. G., Wiese R. G., and Fyfe W. S. (1994) Precipitation of carbonate minerals by microorganisms: Implications for silicate weathering and the global carbon dioxide budget. Geomicrobiol. J. 12, 1-13.

Fischer W. R. and Schwertmann U. (1975) The formation of hematite from amorphous iron(III)hydroxide. Clays Clay Miner. 23, 33-37.

Fredrickson J. K. et al. (1997) Pore-size constraints on the activity and survival of subsurface bacteria in a late Cretaceous shale-sandstone sequence, northwestern New Mexico. Geomicrobiol. J. 14, 183-202.

Gautier D. L. (1982) Siderite concretions: Indicators of early diagenesis in the Gammon shale (Cretaceous). J. Sediment. Petrol. 52, 859871.

Gorby Y. A., Beveridge R. J., and Blakemore R. P. (1988) Characterization of the bacterial magnetosome membrane. J. Bacteriol. 170, $834-841$.

Gorby Y. A., Amonette J. E., and Fruchter J. S. (1995) Remediation of subsurface materials by a metal-reducing bacterium. In Proceedings of the 33rd Hanford Life Sciences Symposium on Health and the Environment - In Situ Remediation: The Scientific Basis for Current And Future Technologies (ed. G. W. Gee and N. R. Wing), pp. 233-248. Battelle Press.

Guerinot M. L. (1994) Microbial iron transport. Ann. Rev. Microbiol. 48, 743-772.

Hansen H. C. B. (1989) Composition, stabilization, and light absorption of $\mathrm{Fe}(\mathrm{II}) \mathrm{Fe}(\mathrm{III})$ hydroxy-carbonate (green rust). Clay Miner. 24, 663-669.

Hansen H. C. B., Borggaard O. K., and Sorensen J. (1994) Evaluation of the free energy of formation of Fe(II)-Fe(III) hydroxide-sulphate (green rust) and it's reduction of nitrite. Geochim. Cosmochim. Acta $\mathbf{5 8}, 2599-2608$.

Heijman C. G., Holliger C., Glaus M. A., Schwarzenbach R. P., and Zeyer J. (1993) Abiotic reduction of 4-chloronitrobenzene to 4-chloroaniline in a dissimilatory iron-reducing enrichment culture. Appl. Environ. Microbiol. 59, 4350-4353.

Heijman C. G., Grieder E., Holliger C., and Schwarzenbach R. P. (1995) Reduction of nitroaromatic compounds coupled to microbial iron reduction in laboratory aquifer columns. Environ. Sci. Technol. 29, 775-783.

Heron G., Tjell J. C., and Christensen T. H. (1994) Oxidation capacity of aquifer sediments. Environ. Sci. Tech. 28, 153-158.

Jolivet J. P., Belleville P., Tronc E., and Livage J. (1992) Influence of $\mathrm{Fe}(\mathrm{II})$ on the formation of the spinel iron oxide in alkaline medium. Clays Clay Miner. 40, 531-539.

Karlin R., Lyle M., and Heath G. R. (1987) Authigenic magnetite formation in suboxic marine sediments. Nature 326, 490-493.
Kazumi J., Haggblom M. M., and Young L. Y. (1995) Degradation of monochlorinated and nonchlorinated aromatic compounds under iron-reducing conditions. Appl. Environ. Microbiol. 61, 4069-4073.

Koch C. B. and Morup S. (1991) Identification of green rust in an ochre sludge. Clay Mineral. 26, 577-582.

Kostka J. E. and Nealson K. H. (1995) Dissolution and reduction of magnetite by bacteria. Environ. Sci. Tech. 29, 2535-2540.

Kung K.-H. and McBride M. B. (1988) Electron transfer processes between hydroquinone and iron oxides. Clays Clay Miner. 36, 303309.

LaKind J. S. and Stone A. T. (1989) Reductive dissolution of goethite by phenolic reductants. Geochim. Cosmochim. Acta 53, 961-971.

Lippmann F. (1973) Sedimentary Carbonate Minerals. Springer-Verlag.

Lovley D. R. (1991a) Dissimilatory Fe(III) and Mn(IV) reduction. Microbiol. Rev. 55, 259-287.

Lovley D. R. (1991b) Magnetite formation during microbial dissimilatory iron reduction. In Iron Biominerals (ed. R. B. Frankel and R. P. Blakemore), pp. 151-166. Plenum Press.

Lovley D. R. (1993) Dissimilatory metal reduction. Ann. Rev. Microbiol. 47, 263-290.

Lovley D. R. and Lonergan D. J. (1990) Anaerobic oxidation of toluene, phenol, and p-cresol by the dissimilatory iron-reducing organism, GS-15. Appl. Environ. Microbiol. 56, 1858-1864.

Lovley D. R. and Phillips E. J. P. (1986) Availability of ferric iron for microbial reduction in bottom sediments of the freshwater tidal Potomac River. Appl. Environ. Microbiol. 52, 751-757.

Lovley D. R. and Phillips E. J. P. (1987) Rapid assay for microbially reducible ferric iron in aquatic sediments. Appl. Environ. Microbiol. 53, 1536-1540.

Lovley D. R. and Phillips E. J. P. (1988) Novel mode of microbial energy metabolism: Organic carbon oxidation coupled to dissimilatory reduction of iron or manganese. Appl. Environ. Microbiol. 54, $1472-1480$.

Lovley D. R., Stolz J. F., Nord G. L., Jr., and Phillips E. J. P. (1987) Anaerobic production of magnetite by a dissimilatory iron-reducing microorganism. Nature 330, 252-254.

Lovley D. R., Phillips E. J. P., and Lonergan D. J. (1991) Enzymatic versus nonenzymatic mechanisms for $\mathrm{Fe}(\mathrm{III})$ reduction in aquatic sediments. Environ. Sci. Technol. 25, 1062-1067.

Lovley D. R., Coates J. D., Blunt-Harris E. L., Phillips E. J. P., and Woodward J. C. (1996) Humic substances as electron acceptors for microbial respiration. Nature 382, 445-448.

Lovley D. R., Fraga J. L., Blunt-Harris E. L., Hayes L. A., Phillips E. J. P., and Coates J. D. (1998) Humic substances as a mediator for microbially catalyzed metal reduction. Acta Hydrochim. Hydrobiol. in press.

Maher B. A. and Taylor R. M. (1988) Formation of ultrafine-grained magnetite in soils. Nature 336, 368-370.

Mann S. (1989) Crystallochemical strategies in biomineralization. In Biomineralization (ed. S. Mann et al.), pp. 35-62. VCH.

Mann S., Sparks N. H. C., Couling S. B., Larcombe M. C., and Frankel R. B. (1989) Crystallochemical characterization of magnetic spinels prepared from aqueous solution. J. Chem. Soc. Faraday Trans. 85, 3033-3044.

McGill J. R., McEananey B., and Smith D. C. (1976) Crystal structure of green rust formed by corrosion of cast iron. Nature 259, 200-201.

Miyata S. (1983) Anion-exchange properties of hydrotalcite-like compounds. Clays Clay Miner. 31, 305-311.

Morel F. M. M. (1983) Principles of Aquatic Chemistry. Wiley.

Mortimer R. J. G. and Coleman M. L. (1997) Microbial influence on the isotopic composition of diagenetic siderite. Geochim. Cosmochim. Acta 61, 1705-1711.

Mortimer R. J. G., Coleman M. L., Rae J. E. (1997) Effect of bacteria on the elemental composition of early diagenetic siderite: Implications for palaeoenvironmental interpretations. Sedimentology 44, $759-765$.

Mozley P. S. and Carothers W. W. (1992) Elemental and isotopic composition of siderite in the Kuparuk Formation, Alaska: Effect of microbial activity and water/sediment interaction on early porewater chemistry. J. Sediment. Petrol. 62, 681-692.

Mozley P. S. and Wersin P. (1992) Isotopic composition of siderite as an indicator of depositional environment. Geology 20, 817-820. 
Myers C. R. and Meyers J. M. (1992) Localization of cytochromes to the outer membrane of anaerobically grown $S$. putrefaciens MR-1. J. Bacteriol. 174, 3429-3438.

Myers C. R. and Myers J. M. (1993) Role of menaquinone in the reduction of fumarate, nitrate, iron(III) and manganese(IV) by $S$ putrefaciens MR-1. FEMS Microbiol. Lett. 114, 215-222.

Myers C. R. and Myers J. M. (1997) Outer membrane cytochromes of S. putrefaciens MR-1: Spectral analysis, and purification of the 83-kDa c-type cytochrome. Biochim. Biophys. Acta 1326, 307-318.

Nealson K. and Saffarini D. (1994) Iron and manganese in anaerobic respiration: environmental significance, physiology, and regulation. Ann. Rev. Microbiol. 48, 311-343.

Olsen S. R. and Sommers L. E. (1982) Phosphorous. In Methods of Soil Analysis, Part 2-Chemical and Microbiological Properties (ed. A. L. Page et al.), pp. 403-430. Amer. Soc. Agron.

Postma D. (1981) Formation of siderite and vivianite and the porewater composition of a recent bog sediment in Denmark. Chem. Geol. 31, 225-244.

Pye K., Dickson J. A. D., Schiavon N., Coleman M. L., and Cox M. (1990) Formation of siderite-Mg-calcite-iron sulphide concretions in intertidal marsh and sandflat sediments, north Norfolk, England. Sedimentology 37, 325-343.

Rajan S., Mackenzie F. T., and Glenn C. R. (1996) A thermodynamic model for water column precipitation of siderite in the Plio-Pleistocene Black Sea. Amer. J. Sci. 296, 506-548.

Roden E. E. and Zachara J. M. (1996) Microbial reduction of crystalline Fe(III) oxides: Influence of oxide surface area and potential for cell growth. Environ. Sci. Technol. 30, 1618-1628.

Schwertmann U. and Murad E. (1983) Effect of $\mathrm{pH}$ on the formation of goethite and hematite from ferrihydrite. Clays Clay Miner. 31, 277284.

Smith R. M. and Martell A. E. (1997) NIST Critically Selected Stability Constants of Metal Complexes Database. Version 3.0. User's Guide and Database Software. NIST Standard Reference Database 46.

Sparks N. H. C., Mann S., Bazylinski D. A., Lovley D. R., Jannasch H. W., and Frankel R. B. (1990) Structure and morphology of magnetite anaerobically-produced by a marine magnetotactic bacterium and a dissimilatory iron-reducing bacterium. Earth Planet. Sci. Lett. 98, 14-22.

Stampfl P. P. (1969) Ein basisches Eisen-II-III-Karabonat in Rost. Corros. Sci. 9, 185-187.

Stone A. T. and Morgan J. J. (1984) Reduction and dissolution of manganese(III) and manganese(IV) oxides by organics. 1. Reaction with hydroquinone. Environ. Sci. Technol. 18, 450-456.

Stookey L. L (1970) Ferrozine-a new spectrophotometric reagent for iron. Anal. Chem 42, 779-781.
Suess E. (1979) Mineral phases formed in anoxic sediments by microbial decomposition of organic matter. Geochim. Cosmochim. Acta 43, 339-352.

Tamaura Y., Yoshida T., and Katsura T. (1984) The synthesis of green rust $\mathrm{II}\left(\mathrm{Fe}_{1}^{\mathrm{III}}-\mathrm{Fe}_{2}^{\mathrm{II}}\right)$ and its spontaneous transformation into $\mathrm{Fe}_{3} \mathrm{O}_{4}$. Bull. Chem. Soc. Japan 57, 2411-2416.

Taylor R. M. (1980) Formation and properties of Fe(II),(III) hydroxy carbonate and its possible significance in soil formation. Clay Mineral. 15, 369-382.

Taylor R. M., Schwertmann U., and Fechter H. (1985) A rapid method for the formation of $\mathrm{Fe}(\mathrm{II}), \mathrm{Fe}(\mathrm{III})$-hydroxy carbonate. Clay Mineral. 20, 147-151.

Tratnyek P. G. (1987) Abiotic reduction of nitro aromatic pesticides in anaerobic laboratory systems designed to model dissolved organic matter. Ph.D. Thesis, Colorado Sch. Mines.

Trolard F., Genin J. M. R., Abdelmoula M., Bourrie G., Humbert B., and Herbillon A. 1997. Identification of a green rust mineral in a redoctomorphic soil by Mössbauer and Raman spectroscopies. Geochim. Cosmochim. Acta 61, 1107-1111.

Tronc E., Belleville P., Jolivet J. P., and Livage J. (1992) Transformation of ferric hydroxide into spinel by FeII adsorption. Langmuir 8, 313-319.

Urrutia M. M., Roden E. E., Fredrickson J. K., and Zachara J. M. (1998) Microbial and surface chemistry controls on reduction of synthetic Fe(III) oxide minerals by the dissimilatory iron-reducting bacterium Shewanella alga. Geomicrobiol. J. 15, 269-291.

Vins J., Subert J., Zapletal V., and Hansousek F. (1987) Preparation and properties of green rust type substances. Collect. Czech. Chem. Comm. 52, 93-102.

Wagman D. D. et al. (1982) The NBS Tables of Chemical Thermodynamic Properties. Selected Values for Inorganic and C1 and C2 Organic Substances in SI Units. J. Phys. Chem. Ref. Data 11, 1-392.

Walker J. C. G. (1984) Suboxic diagenesis in banded iron formations. Nature 309, 340-342.

Wallmann K., Hennies K., Konig I., Petersen W., and Knauth H.-D. (1993) New procedure for determining reactive $\mathrm{Fe}(\mathrm{III})$ and $\mathrm{Fe}(\mathrm{II})$ minerals in sediments. Limnol. Oceanogr. 38, 1803-1812.

Wersin P., Charlet L., Karthein R., and Stumm W. (1989) From adsorption to precipitation: Sorption of $\mathrm{Mn} 2+$ on FeCO3. Geochim. Cosmochim. Acta 53, 2787-2796.

Williams R. J. P. (1989) The functional forms of biominerals. In Biomineralization (ed. S. Mann et al.), pp. 1-34. VCH.

Zachara J. M., Fredrickson J. K., Li S. W., Kennedy D. W., Smith S. C., and Gassman P. L. (1998) Bacterial reduction of crystalline Fe(III) oxides in single phase suspensions and subsurface materials. Amer. Mineral. 83, 1426-1443. 